\title{
Review:
}

\section{Significance of physicochemical and uptake kinetics in controlling the toxicity of metallic nanomaterials to aquatic organisms"}

\author{
Jian WANG, Wen-xiong WANG ${ }^{\dagger *}$ \\ (Division of Life Science, The Hong Kong University of Science and Technology, Clearwater Bay, Kowloon, Hong Kong, China) \\ †E-mail: wwang@ust.hk
}

Received Apr. 25, 2014; Revision accepted June 20, 2014; Crosschecked July 18, 2014

\begin{abstract}
With the extensive applications of metallic-based nanomaterials (MNs), concerns are growing of their potential impact on aquatic organisms. Unlike traditional metal pollutants, MNs have different surface properties and compositions, which may modify their impact on aquatic environments as well as their bioavailability to aquatic organisms. Kinetic processes of MNs, such as dissolution, stabilization, aggregation, and sedimentation, are important in determining their bioavailability and subsequent toxicity to aquatic organisms. Among all of the physicochemical kinetics, the dissolution of MNs attracts the most attention, due to their potential toxicity generated by dissolved ions. This review summarizes the dissolution behavior of three common MNs, i.e., $\mathrm{ZnO}$ nanoparticles ( $\mathrm{ZnO}-\mathrm{NPs})$, Ag nanoparticles (Ag-NPs), and $\mathrm{TiO}_{2}$ nanoparticles $\left(\mathrm{TiO}_{2}-\mathrm{NPs}\right)$, in toxicological studies. A kinetic model was developed to evaluate the contribution of dissolved ion on the total MN accumulation. Finally, toxicological data of the MNs to algae, zooplankton, and fish are summarized and interpreted based on their kinetics. Different dissolution rates were observed for $\mathrm{ZnO}-\mathrm{NPs}$, Ag-NPs, and $\mathrm{TiO}_{2}-\mathrm{NPs}$, and their solubility also varied during different toxicological studies, leading to a variable but increasing waterborne ion concentration during exposure. The bioavailability of these MNs and corresponding ions also varied for different aquatic organisms (e.g., algae, zooplankton, and fish). Specifically, the MNs appeared to be more bioavailable to daphnids, rendering a minor contribution of ion during short-term exposure. Generally, dissolved ion contributed partially to toxicity of $\mathrm{ZnO}-\mathrm{NPs}$ and Ag-NPs, while the toxicity of $\mathrm{TiO}_{2}$-NPs was mainly due to the generated reactive oxygen species (ROS). Additionally, the role of dissolved ion in both MN bioaccumulation and toxicity intensified during chronic exposure as a result of dissolution, thus it is critical to monitor the dissolution of MNs in toxicological studies. This review emphasizes the importance of integrating physicochemical kinetics and uptake kinetics in evaluating the bioavailability and toxicity of both MNs and dissolved ions.
\end{abstract}

Key words: Metallic-based nanomaterials (MNs), Dissolution, Kinetics, Aquatic organisms, Toxicity doi:10.1631/jzus.A1400109

Document code: A

CLC number: X52

\section{Introduction}

The application of metallic-based nanomaterials (MNs) now exists in every corner of modern life, e.g., cosmetics, textiles, and paints. For some MNs, e.g., $\mathrm{TiO}_{2}$ nanoparticles $\left(\mathrm{TiO}_{2}-\mathrm{NPs}\right)$ and $\mathrm{ZnO}$ nanoparticles (ZnO-NPs), the annual worldwide production exceeds hundreds of tons (Piccinno et al., 2012). The

\footnotetext{
Corresponding author

* Project supported by the General Research Fund of the Hong Kong Research Grants Council (No. 663011), China

(c) Zhejiang University and Springer-Verlag Berlin Heidelberg 2014
}

extensive use of these MNs will eventually result in an increased $\mathrm{MN}$ input into the aquatic environment. Due to the complexity of the environmental matrix in affecting the analytical processes (Farré et al., 2009), reports of $\mathrm{MN}$ concentrations in the aquatic environment are still limited, but the concerns toward the potential impact of these MNs on aquatic organisms are growing (Griffitt et al., 2008). Various toxicological studies have been conducted to screen the toxicity of MNs on aquatic organisms (e.g., algae, zooplankton, and fish) (Baun et al., 2008; Farré et al., 2009; Scown et al., 2010). However, unlike the traditional trace metal pollutants, the MNs are very 
dynamic in an aquatic environment. Kinetic processes, such as aggregation, dissolution, and sedimentation, take place immediately after these MNs are released into the aquatic environment (Fig. 1) (Klaine et al., 2008). Thus, greater attention should be paid to the physicochemical properties of these MNs in toxicological studies, because they can significantly affect the kinetic processes mentioned above (Auffan et al., 2010; Podila and Brown, 2013).

In connection with MNs toxicity, one of the most common debates is the role of dissolved ion in contributing to MNs' toxicity (Lubick, 2008; Shaw and Handy, 2011; Misra et al., 2012). To separate the impact of ions in MN toxicity testing, most studies also run a parallel ion toxicity test for comparison of the results. However, MNs as dynamic entities are not stable and the ion concentration keeps increasing within the dissolution period, which differs from traditional static exposures with a relatively constant exposure concentration. Therefore, a kinetic interpretation of both the accumulation and resulting toxicity is needed in order to define the contribution of ions. For this purpose, the present study reviews the dissolution of three types of MNs, i.e., ZnO-NPs, Ag nanoparticles (Ag-NPs), and $\mathrm{TiO}_{2}-\mathrm{NPs}$, in toxicological studies. These three types of MNs are mainly chosen because of their different dissolution behavior. The subsequent uptake of these MNs and the corresponding ions within algae, zooplankton, and fish are reviewed. We then develop a kinetic uptake model in Daphnia magna by integrating the dissolution kinetics and uptake kinetics of MNs to quantify the contribution of ions during short-time exposure. Finally, the MNs toxicity data (mostly acute data) are gathered and interpreted based on the kinetic process.

\section{Dissolution of $\mathrm{MNs}$ in the aquatic environment}

Once released into the aquatic environment, the dissolution of some MNs will immediately occur, raising a question whether the toxicity of MNs is due to the ions or MNs. This has been a central question in nanotoxicology. Before such a question can be realistically answered, the dynamic dissolution of these MNs in the studied medium needs to be understood. Several environmental factors (e.g., dissolved natural organic matter, ionic strength, type of electrode, and $\mathrm{pH})$ as well as the intrinsic properties of the MNs (e.g., size, aggregation state, coating, and concentration) affect this process (Klaine et al., 2008). To describe the dissolution of MNs, models evaluating MNs dissolution are briefly discussed and the solubility of the MNs mentioned above in nanotoxicological studies are elaborated.

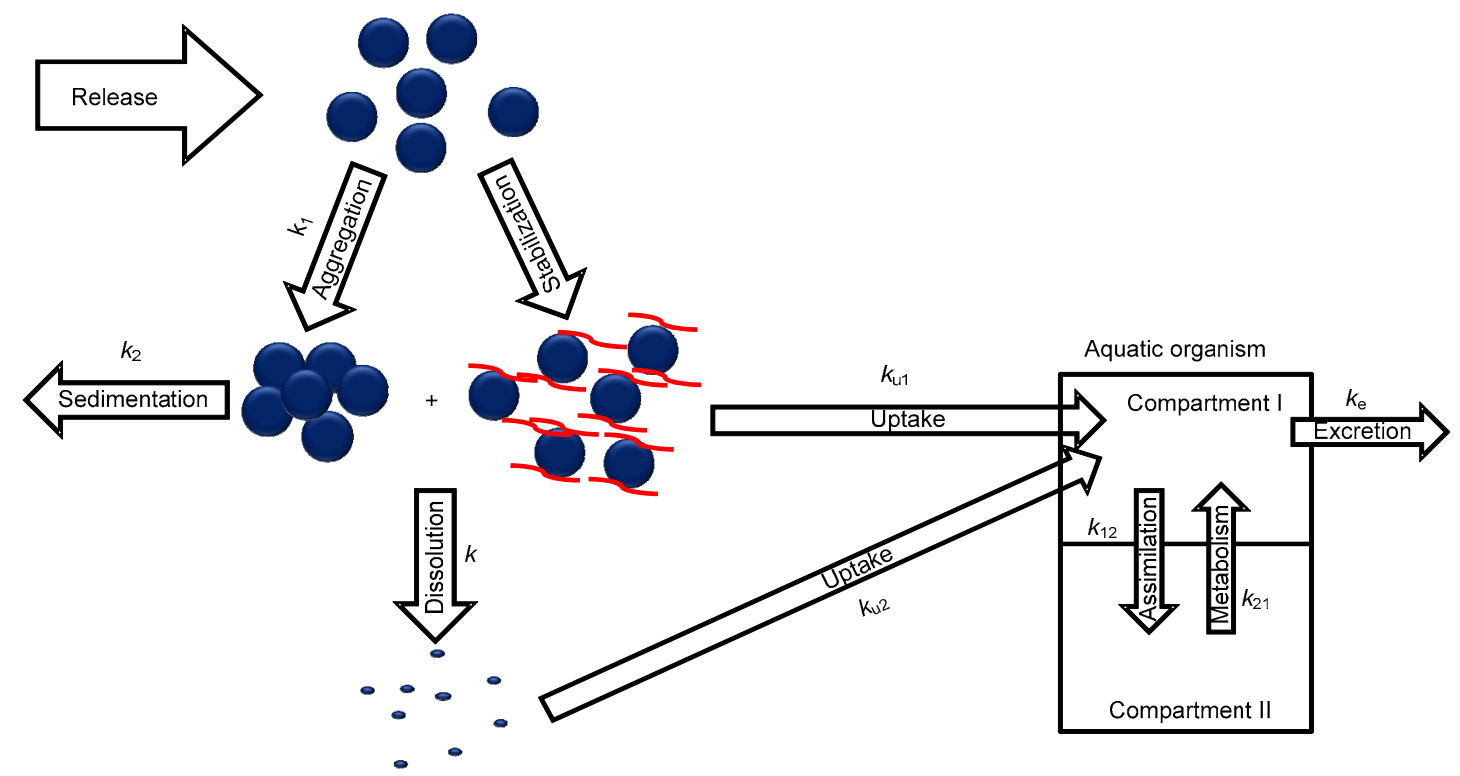

Fig. 1 Kinetic scheme of MNs in aquatic environments

$k, k_{1}$, and $k_{2}$ are the rate constants for dissolution, aggregation, and sedimentation of MNs, respectively. $k_{\mathrm{u} 1}$ and $k_{\mathrm{u} 2}$ are the uptake rate constants for MNs and dissolved ions, respectively. $k_{12}$ and $k_{21}$ are the rate constants for metals being transferred between compartments I and II, respectively. $k_{\mathrm{e}}$ is the efflux rate constant of silver 


\subsection{Kinetic models for dissolution of MNs}

In simply considering the particle surface as a major factor affecting particle dissolution, the traditional Noyes-Whitney equation is frequently applied (Dokoumetzidis and Macheras, 2006). A common mathematic expression is given as

$$
\frac{\mathrm{d} m}{\mathrm{~d} t}=\frac{D A}{h}\left(C_{\mathrm{s}}-C\right),
$$

where $\mathrm{d} m / \mathrm{d} t$ is the dissolution rate, $D$ is the diffusion coefficient, $A$ is the surface area, $h$ is the thickness of diffusion layers, $C_{\mathrm{s}}$ and $C$ are the saturated and bulk concentrations, respectively. Thus, particles with a smaller size (relatively high surface area) are considered to have a faster dissolution rate. $h$ has been experimentally found to decrease with particle size leading to faster transport of solvated molecules to bulk solution and hence a more rapid dissolution (Tinke et al., 2005). The Noyes-Whitney equation has been applied in predicting the initial drug release rate in MNs by comparing this with the bulk materials (Heng et al., 2008). However, the direct calculation of the dissolution rate using the Noyes-Whitney equation is difficult due to the lack of a reliable theoretical approach for their prediction. $D$ and $h$ are often determined experimentally (MacInnis and Brantley, 1992; Wang and Flanagan, 2002). Alternatively, the Ostward-Freundlich equation derived from thermodynamics provides a solution for quantifying the solubility of particles (Hunter, 2001), which can be given as

$$
\frac{S}{S_{\circ}}=\exp \left(\frac{2 \gamma V}{R T r}\right)
$$

where $S$ is the solubility of fine particles with an inscribed radius $r, S_{0}$ is the solubility of the bulk material, $V$ is the molar volume $\left(\mathrm{m}^{3} / \mathrm{mol}\right), \gamma$ is the surface energy $\left(\mathrm{J} / \mathrm{m}^{2}\right), R$ is the gas constant, and $T$ is the temperature $(\mathrm{K})$. A prediction of the particle dissolution rate needs a precise estimation of $\gamma$, but it differs with the current particle surface morphology and type (Mihranyan and Strømme, 2007). David et al. (2012) estimated the $\gamma$ of ZnO-NPs by analyzing the equilibrium free $\mathrm{Zn}^{2+}$ concentration in a medium with different sized ZnO-NPs. They were able to predict the dissolution rate of large $\mathrm{ZnO}-\mathrm{NPs}$ aggregates. However, complications arise in the applications of the Ostwald-Freundlich equations for very small particles $(<$ several nanometers in diameter), since the surface stress (the reversible work per unit area required to elastically stretch a surface) will affect the surface energy (Hofmeister et al., 1997). The accompanying aggregation process, especially at the beginning of dissolution, leads to an increasing diameter and modifies the surface morphology, which is considered as the major reason for poor prediction of the ZnO-NPs (4 nm) dissolution (Bian et al., 2011).

An empirical model on Ag-NPs (50 nm) dissolution was proposed by Liu and Hurt (2010) by considering the impacts of $\mathrm{pH}$, temperature, dissolved oxygen, and natural organic matters. This empirical model was less applicable for Ag-NPs with different sizes, since their activation energy for the dissolution process was different (Zhang et al., 2011). Most of the previous dissolution studies only determined a single or several alternate factors affecting MNs' dissolution, and a comprehensive mathematical prediction of the dissolution process in complex environmental matrix is still lacking. Since MNs with different chemical components may dissolute differently, representative MNs (e.g., ZnO-NPs, Ag-NPs, and $\mathrm{TiO}_{2}$-NPs) are chosen and the favorable environmental conditions for their dissolution, as well as the dissolution behavior of MNs in toxicological studies, are discussed in the following sections.

\subsection{ZnO-NPs}

The dissolution process of $\mathrm{ZnO}-\mathrm{NPs}$ in water firstly involves the hydration of the surface $\mathrm{ZnO}$ to $\mathrm{Zn}(\mathrm{OH})_{2}$ (Han et al., 2010) and can be simply written as (David et al., 2012)

$$
\mathrm{ZnO}(\mathrm{s})+\mathrm{H}_{2} \mathrm{O}(\mathrm{l}) \leftrightarrow \mathrm{Zn}^{2+}(\mathrm{aq})+2 \mathrm{OH}^{-}(\mathrm{aq})
$$

Neutralization of the generated $\mathrm{OH}^{-}$can facilitate the dissolution process. Thus, a low $\mathrm{pH}$ was favorable for $\mathrm{ZnO}$-NPs dissolution, as it was discovered that the maximum $\mathrm{Zn}^{2+}$ concentration increased by almost 100 times when the medium $\mathrm{pH}$ decreased from 9 to 7 (Miao et al., 2010). Along with $\mathrm{pH}$, the increasing ionic strength also facilitated the dissolution by providing binding ligands (e.g., $\mathrm{Cl}^{-}$and $\mathrm{SO}_{4}{ }^{2-}$ ) to dissolved $\mathrm{Zn}^{2+}$. Temperature can also affect the 
dissolution of $\mathrm{ZnO}-\mathrm{NPs}$; more dissolution of $\mathrm{ZnO}$ NPs in the Roswell Park Memorial Institute medium was observed at $20{ }^{\circ} \mathrm{C}$ than at $37{ }^{\circ} \mathrm{C}$ (Reed et al., 2012). The impact of natural organic matter depends on whether they are acting as chelating agents or blocking agents (adsorbed on the particle surface) (Miao et al., 2010; Mudunkotuwa et al., 2012). Remarkably, re-precipitation of dissolved $\mathrm{Zn}^{2+}$ occurred when they reacted with carbonate $\left(\mathrm{CO}_{3}{ }^{2-}\right)$ or phosphate $\left(\mathrm{PO}_{4}{ }^{3-}\right)$ forming precipitates (e.g., $\mathrm{ZnCO}_{3}$ and $\left.\mathrm{Zn}_{3}\left(\mathrm{PO}_{4}\right)_{2}\right)$ (Pan et al., 2010; Reed et al., 2012).

The time required for $\mathrm{ZnO}-\mathrm{NPs}$ to achieve saturable $\mathrm{Zn}^{2+}$ concentration varied in different toxicological studies. David et al. (2012) demonstrated that the dissolution of ZnO-NPs (e.g., 20 and $71 \mathrm{~nm}$ ) reached equilibrium at about $100 \mathrm{~min}$ and fast dissolution was observed within the first $20 \mathrm{~min}$ in a buffered medium ( $\mathrm{pH} 7.7-8.4$, ionic strength $0.1 \mathrm{~mol} / \mathrm{L}$ ). Fast dissolution was also observed within the first $1 \mathrm{~h}$ in another dissolution kinetic study of $4 \mathrm{~nm} \mathrm{ZnO}-\mathrm{NPs}$ and equilibrium was reached at about $10 \mathrm{~h}$ (Bian et al., 2011), whereas a longer time was needed (e.g., 50$70 \mathrm{~h}$ ) in some toxicological studies (Franklin et al., 2007; Wong et al., 2010; Peng et al., 2011). For most $\mathrm{ZnO}-\mathrm{NPs}$ toxicological studies, dissolution kinetics was not quantified and only a few studies measured the final dissolved $\mathrm{Zn}$ concentration in the medium (Table 1). The percentage of dissolved $\mathrm{Zn}$ also varied for different $\mathrm{ZnO}-\mathrm{NPs}$ and testing systems, ranging from $0.19 \%$ to $20 \%$. Therefore, it is difficult to draw a consensus of the percentage of dissolved $\mathrm{Zn}$ in these toxicological studies. A typical dissolution curve of ZnO-NPs is simulated in Fig. 2a (p.578), assuming $10 \%$ dissolution and a $1 \mathrm{~h}^{-1}$ dissolution rate (for details, see Section 3.3). Consistent with other kinetic studies, the dissolution process reached temporal equilibrium within several hours, which was shorter than the traditional toxicological study duration (e.g., 48-96 h). More evidence suggested that the dissolution continued slowly during prolonged exposure (e.g., chronic $21 \mathrm{~d}$ exposure), during which all $\mathrm{ZnO}-\mathrm{NPs}$ were considered to dissolute totally (Lopes et al., 2014).

\subsection{Ag-NPs}

A redox reaction was involved in the dissolution process of Ag-NPs with the oxidation of zero-valent $\mathrm{Ag}$ to $\mathrm{Ag}^{+}$on the particle surface (Marambio-Jones and Hoek, 2010), which is given as

$$
\mathrm{Ag}(\mathrm{s})+\frac{1}{2} \mathrm{O}_{2}(\mathrm{aq})+2 \mathrm{H}^{+}(\mathrm{aq}) \leftrightarrow 2 \mathrm{Ag}^{+}(\mathrm{aq})+\mathrm{H}_{2} \mathrm{O}(1)
$$

High $\mathrm{H}^{+}$and $\mathrm{O}_{2}$ concentrations were favorable for the dissolution reaction, which was confirmed in a dissolution kinetic study conducted by Liu and Hurt (2010). Also, Ag-NPs with a smaller size provided more surface area for this reaction, and the smaller citrate coated Ag-NPs had the fastest $\mathrm{Ag}^{+}$release rate (Zhang et al., 2011; Ma et al., 2012). However, the dissolution of Ag-NPs was inhibited when they were stabilized by some surfactants (e.g., Tween 80 and sodium dodecyl sulfate) even when they were not aggregated, presumably due to the build-up of a barrier between the particle and oxidants (Li et al., 2012). In a natural environment, the presence of natural organic matter could well stabilize Ag-NPs from aggregation (Delay et al., 2011), whereas their impact on Ag-NPs dissolution depended on the mechanism of dissolved organic matter sorption as well as the solution composition (Brantley, 2008). Although increasing salinity can provide more binding ligands (e.g., $\mathrm{Cl}^{-}$) for dissolved Ag, Ag-NPs preceded at a fast aggregation in high ionic environments and a declining dissolution rate was observed (Liu and Hurt, 2010). However, as a thermodynamic unstable form, Ag-NPs were generally considered to go through continuous dissolution in aquatic environments containing dissolved oxygen (Liu and Hurt, 2010; Fabrega et al., 2011).

Compared with ZnO-NPs, Ag-NPs were relatively stable during toxicological exposure. Although the proportion of dissolved $\mathrm{Ag}$ also varied remarkably in different toxicological studies (Table 1), most of this dissolved $\mathrm{Ag}$ came from the initial rapid dissolution or from the stock. Sotiriou et al. (2012) found that the rapid dissolution of Ag occurred within $5 \mathrm{~min}$, which was far shorter than the regular preparation time in toxicological studies. The subsequent slow dissolution was negligible for most of the short-term toxicity tests (e.g., 24-96 h) (Griffitt et al., 2009; Laban et al., 2010; Zhao and Wang, 2011; Yang et al., 2012). However, the dissolved Ag built up gradually with the extension of the duration time and $100 \%$ dissolution was achieved in air-saturated deionized water after $130 \mathrm{~d}$ (Liu and Hurt, 2010). As another important source of dissolved Ag, the dissolution of stock Ag-NPs solutions also preceded progressively at various storage temperatures, ranging from $10 \%$ to $70 \%$ after $100 \mathrm{~d}$ for citrate coated Ag-NPs (Kittler 
Table 1 Solubility of ZnO-NPs and Ag-NPs in toxicological studies

\begin{tabular}{|c|c|c|c|c|c|c|c|c|c|c|}
\hline \multirow[b]{2}{*}{$\begin{array}{l}\text { NPs } \\
\text { type }\end{array}$} & \multicolumn{3}{|c|}{ Particle characterization } & \multirow[b]{2}{*}{$\begin{array}{c}\text { Test } \\
\text { medium }\end{array}$} & \multirow[b]{2}{*}{$\begin{array}{l}\text { Separation } \\
\text { method }\end{array}$} & \multirow{2}{*}{$\begin{array}{l}\text { Dissolu- } \\
\text { tion test } \\
\text { duration } \\
\text { (h) }\end{array}$} & \multirow[b]{2}{*}{$\begin{array}{l}\text { Total } \\
\text { conc. } \\
(\mathrm{mg} / \mathrm{L})\end{array}$} & \multirow[b]{2}{*}{$\begin{array}{l}\text { Ion } \\
\text { conc. } \\
\text { (mg/L) }\end{array}$} & \multirow[b]{2}{*}{$\begin{array}{l}\text { Solubility } \\
\text { (\%) }\end{array}$} & \multirow[b]{2}{*}{ Reference } \\
\hline & $\begin{array}{l}\text { TEM } \\
\text { Size } \\
(\mathrm{nm})\end{array}$ & $\begin{array}{l}\text { DLS size } \\
(\mathrm{nm})\end{array}$ & $\begin{array}{c}\text { Zeta- } \\
\text { potential } \\
(\mathrm{mV})\end{array}$ & & & & & & & \\
\hline \multirow[t]{12}{*}{$\begin{array}{l}\mathrm{ZnO-} \\
\mathrm{NPs}\end{array}$} & 30 & $73-480$ & & $\begin{array}{c}\mathrm{FW} \\
(\mathrm{pH} 7.6)\end{array}$ & Dialyze & 72 & 100 & 16 & 16.0 & $\begin{array}{l}\text { Franklin et al., } \\
2007\end{array}$ \\
\hline & 26.2 & 2300 & & $\begin{array}{l}\mathrm{SW}(\mathrm{pH} 8.0, \\
30 \mathrm{psu})\end{array}$ & $\begin{array}{l}\text { Filtration } \\
(0.1 \mu \mathrm{m})\end{array}$ & 96 & 61.2 & 3.7 & 5.8 & $\begin{array}{l}\text { Wong et al., } \\
2010\end{array}$ \\
\hline & 20 & 1030 & -39.4 & $\mathrm{FW}$ & $\begin{array}{l}\text { Centrifugation } \\
(5000 \mathrm{r} / \mathrm{min})\end{array}$ & 144 & 816.5 & 1.54 & 0.2 & Ji et al., 2011 \\
\hline & 6.3 & $313-2149$ & & SW & $\begin{array}{l}\text { Centrifugation }(8300 g) \\
\text { and filtration }(0.05 \mu \mathrm{m})\end{array}$ & 96 & 31 & 1.59 & 5.1 & $\begin{array}{l}\text { Peng et al., } \\
2011\end{array}$ \\
\hline & 15.7 & $363-1588$ & & SW & $\begin{array}{l}\text { Centrifugation }(8300 g) \\
\text { and filtration }(0.05 \mu \mathrm{m})\end{array}$ & 96 & 31 & 1.41 & 4.6 & $\begin{array}{l}\text { Peng et al., } \\
\quad 2011\end{array}$ \\
\hline & 30 & $142-517$ & & $\begin{array}{c}\mathrm{FW} \\
(\mathrm{pH} 7.6)\end{array}$ & Centrifugation $\left(1 \times 10^{4} g\right)$ & 24 & 81.6 & 6 & 7.5 & Bai et al., 2010 \\
\hline & 30 & $1061-4533$ & -3 & $\begin{array}{c}\mathrm{FW} \\
(\mathrm{pH} 8.3)\end{array}$ & $\begin{array}{l}\text { Centrifugation }(19064 \mathrm{~g}) \\
\text { and filtration }(0.2 \mu \mathrm{m})\end{array}$ & 48 & 100 & $0.36-0.50$ & $0.4-0.5$ & $\begin{array}{l}\text { Lopes et al., } \\
2014\end{array}$ \\
\hline & $80-100$ & $1353-3560$ & -3 & $\begin{array}{c}\mathrm{FW} \\
(\mathrm{pH} 8.3)\end{array}$ & $\begin{array}{l}\text { Centrifugation }(19064 g) \\
\text { and filtration }(0.2 \mu \mathrm{m})\end{array}$ & 48 & 100 & $0.34-0.43$ & $0.3-0.4$ & $\begin{array}{l}\text { Lopes et al., } \\
2014\end{array}$ \\
\hline & $>200$ & $1565-3365$ & -15 & $\begin{array}{c}\text { FW } \\
(\mathrm{pH} 8.3)\end{array}$ & $\begin{array}{l}\text { Centrifugation }(19064 g) \\
\text { and filtration }(0.2 \mu \mathrm{m})\end{array}$ & 48 & 100 & $0.3-0.8$ & $0.3-0.8$ & $\begin{array}{l}\text { Lopes et al., } \\
2014\end{array}$ \\
\hline & 27.2 & & & FW & $\begin{array}{l}\text { Ultra-filtration } \\
(10 \mathrm{kDa})\end{array}$ & 24 & 2 or 9 & 0.4 & $4.4-20$ & $\begin{array}{l}\text { Poynton et al., } \\
\quad 2011\end{array}$ \\
\hline & $<200$ & & & FW & $\begin{array}{l}\text { Centrifugation } \\
\quad\left(3 \times 10^{5} g\right)\end{array}$ & 48 & 81.6 & 1.2 & 1.5 & $\begin{array}{l}\text { Wiench et al., } \\
\quad 2009\end{array}$ \\
\hline & 20 & 2196 & & $\begin{array}{c}\mathrm{FW} \\
(\mathrm{pH} 8.0)\end{array}$ & Filtration $(0.05 \mu \mathrm{m})$ & 96 & 8.16 & 1.01 & 10.1 & $\begin{array}{l}\text { Zhu et al., } \\
\text { 2009b }\end{array}$ \\
\hline \multirow[t]{19}{*}{$\begin{array}{l}\text { Ag- } \\
\text { NPs }\end{array}$} & 25 & 44 & -36.6 & $\begin{array}{c}\mathrm{FW} \\
(\mathrm{pH} 7.8)\end{array}$ & $\begin{array}{c}\text { Diffusive gradient } \\
\text { in thin films technique }\end{array}$ & 192 & 5.6 & 0.048 & 0.9 & $\begin{array}{l}\text { Navarro et al., } \\
2008 \mathrm{a}\end{array}$ \\
\hline & 25 & 44 & & $\begin{array}{c}\text { FW } \\
(\mathrm{pH} 7.8)\end{array}$ & Ultra-filtration (3 kDa) & 3 & 530 & $3.71-4.24$ & $0.7-0.8$ & $\begin{array}{l}\text { Navarro et al., } \\
\text { 2008a }\end{array}$ \\
\hline & 25 & 44 & -36.6 & $\begin{array}{c}\text { FW } \\
(\mathrm{pH} 7.8)\end{array}$ & Electrode & 192 & NA & NA & $0.7-1.2$ & $\begin{array}{l}\text { Navarro et al., } \\
2008 \mathrm{a}\end{array}$ \\
\hline & $60-70$ & & & $\begin{array}{c}\mathrm{SW} \\
(\mathrm{pH} 8.2)\end{array}$ & Ultra-filtration (1 kDa) & 168 & 495100 & 2360 & 0.5 & $\begin{array}{l}\text { Miao et al. } \\
\quad 2009\end{array}$ \\
\hline & 60 & 307 & -28.5 & $\begin{array}{l}\text { FW } \\
(\mathrm{pH} 7)\end{array}$ & $\begin{array}{l}\text { Filtration } \\
(0.45 \mu \mathrm{m})\end{array}$ & 24 & $\begin{array}{c}10- \\
10000\end{array}$ & $2.2-0.55$ & $\begin{array}{l}0.0055 \\
-22\end{array}$ & $\begin{array}{l}\text { Oukarroum et } \\
\text { al., } 2012\end{array}$ \\
\hline & 60 & 449 & -15.0 & $\begin{array}{c}\mathrm{SW} \\
(\mathrm{pH} 6)\end{array}$ & $\begin{array}{l}\text { Filtration } \\
(0.45 \mu \mathrm{m})\end{array}$ & 24 & $\begin{array}{c}10- \\
10000\end{array}$ & $1.3-7.6$ & $0.8-13$ & $\begin{array}{l}\text { Oukarroum et } \\
\text { al., } 2012\end{array}$ \\
\hline & $10-50$ & $77-310$ & & $\mathrm{FW}$ & $\begin{array}{l}\text { Centrifugation } \\
\quad\left(1 \times 10^{5} g\right)\end{array}$ & 48 & NA & NA & $2-8$ & $\begin{array}{l}\text { Kennedy et al., } \\
2010\end{array}$ \\
\hline & $21-60$ & & & FW & $\begin{array}{l}\text { Centrifugation } \\
(15000 \mathrm{r} / \mathrm{min}) \\
\text { and filtration }(20 \mathrm{~nm})\end{array}$ & 96 & $\begin{array}{l}62.5- \\
20000\end{array}$ & $23-94$ & $0.5-3.7$ & $\begin{array}{l}\text { Laban et al., } \\
\quad 2010\end{array}$ \\
\hline & 26.6 & & -27 & FW & Filtration $(0.2 \mu \mathrm{m})$ & 48 & 51 & $4.2-0.9$ & $1.8-8.2$ & $\begin{array}{l}\text { Griffitt et al., } \\
\quad 2009\end{array}$ \\
\hline & $\begin{array}{c}26.6 \\
(\mathrm{SEM})\end{array}$ & & -27 & $\begin{array}{c}\mathrm{FW} \\
(\mathrm{pH} 8.2)\end{array}$ & $\begin{array}{l}\text { Centrifugation } \\
\left(1 \times 10^{6} g\right)\end{array}$ & 48 & NA & NA & 0.07 & $\begin{array}{l}\text { Griffitt et al., } \\
2008\end{array}$ \\
\hline & 20 & $40-50$ & -19.6 & FW & Ultra-filtration (3 kDa) & 48 & NA & NA & $0.5-1.0$ & $\begin{array}{l}\text { Zhao and Wang, } \\
2011\end{array}$ \\
\hline & $<100$ & 124 & -22.5 & FW & Ultra-filtration (3 kDa) & 48 & $10-50$ & $0.37-1.0$ & $2.4-4.0$ & $\begin{array}{l}\text { Zhao and Wang, } \\
\text { 2012a }\end{array}$ \\
\hline & $10-20$ & 80 & -19.5 & FW & Ultra-filtration (3 kDa) & 48 & $1-8$ & $0.27-0.98$ & $12.3-27$ & $\begin{array}{l}\text { Zhao and Wang, } \\
\text { 2012a }\end{array}$ \\
\hline & $10-20$ & 65 & -22.6 & FW & Ultra-filtration (3 kDa) & 24 & 1000 & 380 & 38.0 & $\begin{array}{l}\text { Zhao and Wang, } \\
\text { 2012a }\end{array}$ \\
\hline & 5 & 90 & & FW & Filtration $(0.025 \mu \mathrm{m})$ & 72 & NA & NA & 25.7 & Yang et al., 2012 \\
\hline & 38 & 70 & & FW & Filtration $(0.025 \mu \mathrm{m})$ & 72 & NA & NA & 2.0 & Yang et al., 2012 \\
\hline & 22 & 70 & & FW & Filtration $(0.025 \mu \mathrm{m})$ & 72 & NA & NA & 2.0 & Yang et al., 2012 \\
\hline & 8 & 110 & & FW & Filtration $(0.025 \mu \mathrm{m})$ & 72 & NA & NA & 1.3 & Yang et al., 2012 \\
\hline & 7 & $50-400$ & & FW & Filtration $(0.025 \mu \mathrm{m})$ & 72 & NA & NA & 0.1 & Yang et al., 2012 \\
\hline
\end{tabular}

TEM: transmission electron microscopy; SEM: scanning electron microscopy; DLS: dynamic light scattering; FW: freshwater; SW: seawater; NA: not available 

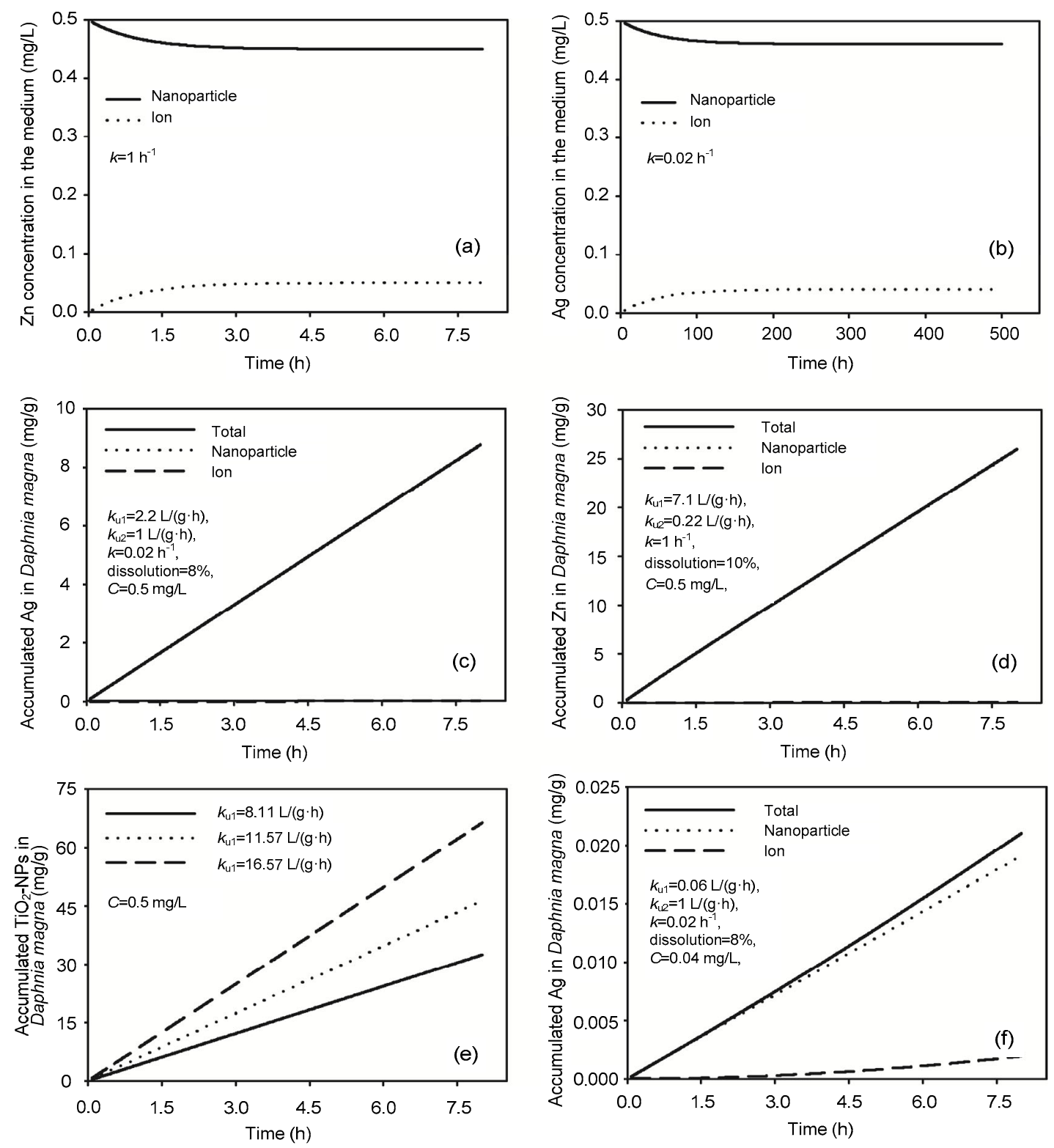

Fig. 2 Modeling results of MNs dissolution and uptake of both MNs and ions by Daphnia magna

(a) Dissolution kinetic of ZnO-NPs (0.5 mg/L); (b) Dissolution kinetic of Ag-NPs (0.5 mg/L); (c) Uptake of Ag-NPs $(0.5 \mathrm{mg} / \mathrm{L})$;

(d) Uptake of ZnO-NPs $(0.5 \mathrm{mg} / \mathrm{L})$; (e) Uptake of different types of $\mathrm{TiO}_{2}-\mathrm{NPs}(0.5 \mathrm{mg} / \mathrm{L})$; (f) Uptake of Ag-NPs $(0.04 \mathrm{mg} / \mathrm{L})$

et al., 2010). Therefore, it is important to perform some clean-up procedures (e.g., dialyze, centrifugation, and resuspension) for aged Ag-NP stocks before conducting nanotoxicological studies. For most of the reviewed toxicological studies, although there were some extreme cases (e.g., 12.3\%-38\%), the dissolved $\mathrm{Ag}$ accounted for less than $8 \%$ of total $\mathrm{Ag}$ mass and the dissolution was rather slow during short-term exposures (Yang et al., 2012; Zhao and Wang, 2011), which can also be inferred from the simulation (Fig. 2b).

\section{$2.4 \mathrm{TiO}_{2}-\mathrm{NPs}$}

$\mathrm{TiO}_{2}$-NPs were rather inert compared to the two above-mentioned MNs, whereas slow hydrolysis still exists especially under some extreme conditions (e.g., low or high $\mathrm{pH}$, high temperature). This can be simply expressed as (Schmidt and Vogelsberger, 2006) 


$$
\mathrm{TiO}_{2}(\mathrm{~s})+(4-n) \mathrm{H}^{+}+(n-2) \mathrm{H}_{2} \mathrm{O} \leftrightarrow \mathrm{Ti}(\mathrm{OH})_{n}^{4-n} .
$$

Similar to Ag-NPs, high $\mathrm{H}^{+}$was favorable for the dissolution of $\mathrm{TiO}_{2}-\mathrm{NPs}$, while the $\mathrm{pH}$ needed to be extremely low to obtain an oblivious dissolution. The bulk $\mathrm{TiO}_{2}$ (rutile) was found less soluble at near neutral $\mathrm{pH}$ (e.g., 4-8), whereas the solubility increased remarkably when $\mathrm{pH}$ decreased to 2 (Knauss et al., 2001). For $\mathrm{TiO}_{2}$-NPs, slight dissolution was observed when the $\mathrm{pH}$ went down to 3 and further increased by $>100$ fold as the $\mathrm{pH}$ decreased to 1.5 , whereas the overall proportion of soluble Ti was less than $0.0038 \%$, even after $125 \mathrm{~d}$ (Schmidt and Vogelsberger, 2006). Therefore, the dissolution of $\mathrm{TiO}_{2}$-NPs was supposed to be rather slow in natural aquatic environment and was often ignored in shortterm toxicological studies (Heinlaan et al., 2008; Zhu et al., 2009a; Ji et al., 2011).

\section{Uptake of NMs by aquatic organisms}

\subsection{Kinetic models on metal and MNs uptake}

Several models have been developed in describing the dissolve uptake of metals. The common linear relationship between uptake and dissolved metal concentration can be written as

$$
I_{\mathrm{w}}=k_{\mathrm{u}} C_{\mathrm{w}} .
$$

This model assumes that the uptake rate $\left(I_{\mathrm{w}}\right)$ of metals is proportional to the metal concentration $\left(C_{\mathrm{w}}\right)$ in water, $k_{\mathrm{u}}$ is the uptake rate constant, and can be obtained by linear regression of different $I_{\mathrm{w}}$ under different $C_{\mathrm{w}}$ during short-term exposure (Wang et al., 1996; Wang and Fisher, 1997). However, in some organisms, the uptake of metals was non-linear as a function of water metal concentration, exhibited by the Freundlich or Michaelis-Mention equation (Wang, 2011). In this review, only the linear model is elucidated.

While different from the pure uptake of metals, the uptake of MNs involves the uptake of several species (e.g., MNs, dissolved ion, and MNs binding ion). Therefore, by assuming that the MNs are homogenously disseminated in the medium and the uptake of the particle and ion is independent, the apparent uptake rate $\left(I_{\mathrm{w}}^{\prime}\right)$ of MNs can be expressed as

$$
I_{\mathrm{w}}^{\prime}=k_{\mathrm{u} 1}\left(C_{\mathrm{NP}}+C_{\mathrm{BI}}\right)+k_{\mathrm{u} 2} C_{\mathrm{w}},
$$

where $C_{\mathrm{NP}}$ is the concentration of the MNs, $C_{\mathrm{BI}}$ is the concentration of MNs binding with ions, and $C_{\mathrm{w}}$ is the concentration of dissolved ions. Similarly, for some "inert" MNs (dissolution was negligible), $k_{\mathrm{ul}}$ can be obtained through linear regression of different $I_{\mathrm{w}}^{\prime}$ under different $C_{\mathrm{NP}}$ during short-term exposure. However, for MNs with significant dissolution, uptake of ions can be deducted either by adding metal chelates (reducing bioavailability of ions) (Zhao and Wang, 2010; 2012b) or deducting the accumulated ions at each time-point by applying the ion uptake kinetic model (Wang and Wang, 2014). $k_{\mathrm{ul}}$ can subsequently be calculated similarly as $k_{\mathrm{u} 2}$ using the obtained "pure" uptake of MNs. Additionally, with the proceeding dissolution, $C_{\mathrm{w}}$ keeps increasing and then leads to an elevated accumulation of ionic metals during exposure. Since the traditional separation methods (e.g., filtration and centrifugation) were unable to distinguish the adsorbed ion from the MNs, the adsorbed ion can be regarded as a part of the MNs. Also, the excretion of accumulated metals can be ignored during short-term exposure, thus the accumulation was equal to the uptake. The total accumulated metals at the time-point $t$ can be simplified as

$$
C=\int_{0}^{t}\left(k_{\mathrm{u} 1} C_{\mathrm{NP}}+k_{\mathrm{u} 2} C_{\mathrm{w}}\right) \mathrm{d} t
$$

As mentioned above, continuous dissolution may proceed during short-term toxicity testing for MNs like ZnO-NPs and Ag-NPs, rendering an increasing ionic metal concentration and decreasing the MNs concentration in the medium. Additionally, considering the variability of bioavailability of different metals in different organisms, the contribution of accumulated ionic metals may also vary. Therefore, the uptake of the above-mentioned three types of MNs in three types of aquatic organisms (i.e., algae, zooplankton, and fish) was evaluated. Finally, the uptake kinetic model was developed for Daphnia magna. 


\subsection{Algae}

For the uptake of MNs into algae, the MNs need to cross two barriers (i.e., cell wall and plasma membrane). Cell walls in algae usually consist of cellulose and semi-permeable, allowing the passage of small molecules. The diameters of these passage pores were in the range of 5-20 nm (Zemke-White et $a l ., 2000)$ and might change during reproduction, with the newly synthesized cell wall being more permeable (Wessels, 1993; Ovečka et al., 2005). Therefore, smaller MNs $(<20 \mathrm{~nm})$ can easily pass the cell walls and there are still some possibilities for the uptake of bigger MNs during reproduction. Once across the cell walls, endocytosis was considered as a major uptake route for incorporating MNs into the cells (Rejman et al., 2004; Clift et al., 2008; Lu et al., 2009; He et al., 2010). A size limitation exists for different endocytosis processes (e.g., phagocytosis and pinocytosis) (Conner and Schmid, 2003; Hirota and Terada, 2012). Beside size, shape, surface charge, surface functional groups, and hydrophilicity of the MNs as well as experimental conditions also affected the uptake process for cells (Kettler et al., 2014). However, a quantitative uptake study of MNs by algae is still lacking, especially for the above-mentioned three types of MNs. As for the uptake of ionic metals (e.g., zinc and silver), Miao and Wang (2004) found that the uptake of zinc (concentration range: $1.2-200 \mathrm{nmol} / \mathrm{L}$ ) by coastal diatom (Thalassiosira pseudonana) exhibited a Michaelis-Mention relationship, with the maximum uptake rate of $26.3 \mu \mathrm{g} /(\mathrm{g} \cdot \mathrm{h})$. A similar relationship was also found in the uptake of zinc by green algae Chlorella vulgaris and Chlorella salina (Ting et al., 1989; Garnham et al., 1992).

As for ionic silver, a continuous uptake was observed (within $60 \mathrm{~min}$ ) in two green algae Pseudokirchneriella subcapitata and Chlorella pyrenoidosa, with the average internalization rates of $1.009 \times 10^{-6} \mu \mathrm{g} /($ cell $\cdot \mathrm{min})$ and $7.37 \times 10^{-7} \mu \mathrm{g} /($ cell $\cdot \mathrm{min})$, respectively (Lee et al., 2004). A non-linear uptake kinetic model in Chlamydomonas reinhardtii was developed by Piccapietra et al. (2012), with uptake rate constants for wild and mutant (no cell wall) of $2.5 \times 10^{-5}-6.9 \times 10^{-5} \mathrm{ml} /($ cell $\cdot \mathrm{min})$ and $1.94 \times 10^{-4}-3.66 \times 10^{-4} \mathrm{ml} /($ cell $\cdot \mathrm{min}), \quad$ respectively, whereas the uptake of Ag-NPs cannot be simulated either by linear or nonlinear models. Studies on the uptake kinetics of $\mathrm{ZnO}-\mathrm{NPs}$ or $\mathrm{TiO}_{2}-\mathrm{NPs}$ in algae were scarce. For reference, the uptake kinetics of CdTe quantum dots (Cd concentration: 1.3-4.7 mg/L) in freshwater alga Ochromonas danica followed the first-order kinetics with the uptake rate constant of $2.15 \times 10^{-9}-4.92 \times 10^{-9} \mathrm{ml} /($ cell.min) (Wang et al., 2013). However, due to the lack of uptake kinetic studies, a systematic comparison between ionic metals and corresponding MNs could not be carried out.

\subsection{Zooplankton}

Uptake of MNs by zooplanktons was considered closely related to their feeding strategies, especially for suspension filter-feeders (e.g., daphnids and copepods). MNs may appear similar as food particles when captured by the animals (Hou et al., 2013). High bioconcentration factors (BCFs) of $\mathrm{TiO}_{2}-\mathrm{NPs}\left(10^{4.75}\right.$ $\left.10^{5.05} \mathrm{~L} / \mathrm{kg}\right)$ and Ag-NPs $\left(10^{3.16}-10^{4.66} \mathrm{~L} / \mathrm{kg}\right)$ have been found in Daphnia magna, with a visually choked gut (Zhu et al., 2010; Zhao and Wang, 2010; 2012a). The capture efficiency increased with increasing particle size (Ward and Kach, 2009; Zhao and Wang, 2012b). However, as mentioned above, dissolution of MNs may proceed continuously during accumulation, and the uptake of dissolved ions may lead to an overestimated BCF of MNs. To quantify the contribution of dissolved ions during the uptake process, three types of MNs (i.e., ZnO-NPs, Ag-NPs, and $\mathrm{TiO}_{2}$-NPs) with dissolution kinetic as well as biokinetic uptake parameters in Daphnia magna were gathered from previous studies. We then model their contribution using Modelmaker 4.0 (Cherwell Scientific Ltd., UK). Kinetic parameters (e.g., solubility, dissolution rate constant, and uptake rate constant) of both MNs and corresponding ions are listed in Table 2. For the modeling, the first-order dissolution kinetics (Noyes-Whitney equation) has been applied in describing the dissolution kinetics of $\mathrm{ZnO}$ NPs and Ag-NPs (Figs. 2a and 2b), which was also proposed in several dissolution kinetic studies (Zhang et al., 2011; David et al., 2012; Piccapietra et al., 2012), whereas the dissolution of $\mathrm{TiO}_{2}-\mathrm{NPs}_{\mathrm{s}}$ was considered negligible. The short-term $(0.5-8 \mathrm{~h})$ uptake of these MNs was found to be proportional to the ambient particle concentration, also exhibiting the first-order kinetics (Zhao and Wang, 2010; 2012a; Li and Wang, 2013). Therefore, a synthetic uptake 
Table 2 Summary of dissolution $(k)$ and uptake rate constants $\left(k_{\mathrm{u}}\right)$ of $\mathrm{ZnO}-\mathrm{NPs}$, Ag-NPs, and $\mathrm{TiO}_{2}$-NPs and corresponding ions

\begin{tabular}{|c|c|c|c|c|}
\hline Agent & Solubility (\%) & $k(\mathrm{~h})$ & $k_{\mathrm{u}}$ in Daphnia magna $(\mathrm{L} /(\mathrm{kg} \cdot \mathrm{h}))$ & Reference \\
\hline $\mathrm{Zn}$ ion & & & $0.094-0.359(\text { at } 2 \mu \mathrm{g} / \mathrm{L})^{*}$ & Tan and Wang, 2008 \\
\hline $\mathrm{ZnO}-\mathrm{NPs}$ & $0.19-20$ & $\begin{array}{c}0.60-0.14 \\
(20-71 \mathrm{~nm})\end{array}$ & $7.02-7.2(46-56 \mathrm{~nm}$, at $0.5-2 \mathrm{mg} / \mathrm{L})$ & $\begin{array}{l}\text { David et al., 2012; } \\
\text { Li and Wang, } 2013\end{array}$ \\
\hline Ag ion & & & $\begin{array}{l}0.26(\text { at } 8-880 \mathrm{ng} / \mathrm{L}) ; \\
0.75-1.34(\text { at } 0.7 \mu \mathrm{g} / \mathrm{L})\end{array}$ & $\begin{array}{l}\text { Lam and Wang, 2006; } \\
\text { Zhao and Wang, 2012b }\end{array}$ \\
\hline Ag-NPs & $0.005-38$ & $\begin{array}{c}0.01-0.55 \\
(4.8-80 \mathrm{~nm})\end{array}$ & $\begin{array}{l}0.25-0.86(20-100 \mathrm{~nm}, \text { at } 1-4 \mu \mathrm{g} / \mathrm{L}) \\
0.06(40-50 \mathrm{~nm}, \text { at } 2-40 \mu \mathrm{g} / \mathrm{L}) ; \\
2.2(40-50 \mathrm{~nm} \text {, at } 40-500 \mu \mathrm{g} / \mathrm{L})\end{array}$ & $\begin{array}{l}\text { Liu and Hurt, 2010; } \\
\text { Zhang et al., 2011; } \\
\text { Zhao and Wang, 2010; 2012b }\end{array}$ \\
\hline $\mathrm{TiO}_{2}$-NPs & 0 & 0 & $5.75-23.6(30-200 \mathrm{~nm}$, at $0.1-10 \mathrm{mg} / \mathrm{L})$ & (Unpublished data) \\
\hline
\end{tabular}

${ }^{*}$ The values in bracket indicate the particle size range and exposure concentration range

kinetic simulation was developed. Considering the variation of solubility, the dissolution, and the uptake rate constant, a generalized value was applied (Figs. 2c-2f). Dissolution (except $\mathrm{TiO}_{2}-\mathrm{NPs}$ ) and uptake of MNs $(0.5 \mathrm{mg} / \mathrm{L})$ are modeled. Specifically, uptake of Ag-NPs at low concentration $(40 \mu \mathrm{g} / \mathrm{L})$ and three types of $\mathrm{TiO}_{2}$-NPs $(50 \mathrm{~nm})$ with different surface properties are also modeled for comparison.

Generally, the contribution of ionic metal to the total accumulated metal in Daphnia magna was not significant (Figs. 2c, 2d, and 2f). Although the uptake rate constant of silver ions was 16.6 folds of the Ag-NPs at a low concentration of Ag-NPs (Zhao and Wang, 2010), the contribution of ionic silver only accounted for $9.1 \%$ of the total accumulated silver (Fig. 2f). For ZnO-NPs with a fast dissolution (Fig. 2a), the contribution of zinc ions was also minor. For uptake at a high concentration $(0.5 \mathrm{mg} / \mathrm{L})$ of MNs, the uptake rate constants varied for different particles, but were generally in the same order and higher than the corresponding ions. Additionally, even for the same sized $\mathrm{TiO}_{2}$-NPs (Fig. 2e), surface properties can significantly affect the uptake rate constants.

In this model, only moderate dissolution (e.g., $8 \%$ for Ag-NPs and $10 \%$ for $\mathrm{ZnO}-\mathrm{NPs}$ ) of MNs was considered. However, in some extreme cases, $27 \%$ of Ag-NPs was dissolved (Zhao and Wang, 2011), and $25.8 \%$ of accumulated silver was estimated to be due to the uptake of ionic Ag. Therefore, it is important to monitor the dissolution behavior of MNs during toxicity studies, especially at low exposure concentrations. Moreover, the impact of surface properties on uptake cannot be ignored when considering the toxicity of same chemical component MNs.

\subsection{Fish}

Gill and digestion tract were considered as the major uptake sites of waterborne MNs in fish (Handy et al., 2008b). Similar to the uptake of ions, MNs firstly need to diffuse through the unstirred layer (USL) formed over the epithelial cells of the gill or gut (Handy and Eddy, 2004; Handy et al., 2008b). Movement of MNs from the bulk water into the USL is controlled by the perikinetic forces (shear forces) at this interface (Handy et al., 2008a). Several factors, such as the speed of the bulk water flow, particle size and shape, and the viscosity of the USL, can affect this process (Handy et al., 2008a). After crossing the USL, MNs can bind with viscous mucus and may be more readily transported for positively charged MNs than for other substances (Smith et al., 2007; Cho et al., 2009). The subsequent uptake of MNs was through the endocytosis of the gill or gut epithelial cells. Detailed uptake mechanisms and subsequent distribution were reviewed by Handy et al. (2008b).

To quantitatively evaluate the uptake of MNs in fish, Wang and Wang (2014) investigated the uptake of Ag-NPs and $\mathrm{AgNO}_{3}$ by Japanese medaka at different salinities (e.g., 1, 5, 15, and $30 \mathrm{psu}$ ). The uptake rate constants $\left(k_{\mathrm{u}}\right)$ of $\mathrm{AgNO}_{3}(0.13-0.93 \mathrm{~L} /(\mathrm{kg} \cdot \mathrm{h})$, $47.6 \mu \mathrm{g} / \mathrm{L})$ were generally higher than those of Ag-NPs $(<0.27 \mathrm{~L} /(\mathrm{kg} \cdot \mathrm{h}), 87 \mu \mathrm{g} / \mathrm{L})$ across all the study salinities. Limited bioavailability of commonly used citrate coated Ag-NPs was observed at high salinities (30 psu), presumably due to the fast aggregation. Similar results were also found in another study (unpublished data), in which the uptake of $\mathrm{AgNO}_{3}$ $(2.1 \mathrm{~L} /(\mathrm{kg} \cdot \mathrm{h}), 0.5-16 \mu \mathrm{g} / \mathrm{L})$ by zebrafish was significantly higher than that of tannic acid coated Ag-NPs 
$(0.3 \mathrm{~L} /(\mathrm{kg} \cdot \mathrm{h}), \quad 100-500 \mu \mathrm{g} / \mathrm{L})$ and citrate coated Ag-NPs $(0.125 \mathrm{~L} /(\mathrm{kg} \cdot \mathrm{h}), 100-500 \mu \mathrm{g} / \mathrm{L})$. The uptake rate constants of $\mathrm{AgNO}_{3}$ quantified in some other freshwater fish (e.g., rainbow trout, fathead minnows, Gulf toadfish, European eel, and midshipman) ranged from 0.979 to $32.38 \mathrm{~L} /(\mathrm{kg} \cdot \mathrm{h}$ ) (Bury et al., 1999; Webb and Wood, 2000; Wood et al., 2002; 2004). It appears that the bioavailability of ionic silver was higher than that of Ag-NPs in freshwater fish, but more kinetic studies are needed to verify this assumption.

For $\mathrm{Zn}$, the $k_{\mathrm{u}}$ of zinc ions in freshwater rainbow trout (Oncorhynchus mykiss) was estimated to be 0.1-0.33 L/(kg·h) (Alsop and Wood, 1999; Barron and Albeke, 2000). In marine fish black sea bream (Acanthopagrus schlegeli) and mangrove snapper (Lutjanus argentimaculatus), the $k_{\mathrm{u}}$ was 0.229 and $0.417 \mathrm{~L} /(\mathrm{kg} \cdot \mathrm{h})$, respectively (Xu and Wang, 2002; Zhang and Wang, 2007). These values were nearly three orders of magnitude lower than that of daphnids. However, no data is available for the $k_{\mathrm{u}}$ of ZnO-NPs, neither is the $\mathrm{TiO}_{2}$-NPs, thus there is a great need to quantify the uptake of these MNs in fish.

\section{Toxicity of MNs in aquatic organisms}

Generally, the toxicity of MNs in aquatic organisms was considered to result from released ions, reactive oxygen species (ROS), or MNs themselves. For specific MNs, the contribution of these components may also vary (Navarro et al., 2008a; Matranga and Corsi, 2012). For MNs, such as ZnO-NPs and Ag-NPs, the toxicity generated from the dissolved ions is usually a major concern (Ma et al., 2013; Reidy et al., 2013), while the toxicity of $\mathrm{TiO}_{2}-\mathrm{NPs}$ was mainly associated with their oxidative stress (Sharma, 2009). The explicit biochemical toxic mechanisms could be found in several reviews (Navarro et al., 2008a; Sharma, 2009; Matranga and Corsi, 2012; Reidy et al., 2013). We will focus on quantitative toxicity data (mostly acute toxicity) of these MNs as well as their corresponding ions. A subsequent interpretation of the observed toxicity is then given from the perspective of kinetic processes, including the physicochemical kinetics of MNs and toxicokinetics of aquatic organisms.

\subsection{Quantitative evaluation of toxicity of MNs: ion or particle?}

The available literature on the toxicity data of $\mathrm{ZnO}-\mathrm{NPs}, \mathrm{Ag}-\mathrm{NPs}$, and $\mathrm{TiO}_{2}$-NPs and corresponding ions on three types of aquatic organisms (i.e., algae, zooplankton, and fish) are listed in Tables 3-5. In general, a great variability of MNs toxicity was observed in different aquatic organisms for different MNs, and the contribution of ions in the toxicity of MNs also varied.

\subsubsection{Algae}

For algae, the estimated 72-h or 96-h IC50/EC50 (IC50 is the $50 \%$ inhibitory concentration; EC50 is the $50 \%$ effective concentration; usually using growth inhibition as the endpoint) of ZnO-NPs ranged from 0.042 to $4.56 \mathrm{mg} / \mathrm{L}$, and the corresponding value for ions was $0.042-3.48 \mathrm{mg} / \mathrm{L}$ (Table 3). Five of the literature reviewed investigated the $72-\mathrm{h}$ or $96-\mathrm{h}$ IC50/EC50 of bulk $\mathrm{ZnO}$, with the values ranging from 0.037 to $3.57 \mathrm{mg} / \mathrm{L}$. Almost $50 \%$ of the literature reviewed attributed the $\mathrm{ZnO}-\mathrm{NPs}$ toxicity mainly to the dissolved zinc ions, whereas the other studies considered the impacts due to specific MNs. Considering the sensitivity of different species, freshwater green alga Pseudokirchneriella subcapitata was the most susceptive (72-h EC50: $<0.05 \mathrm{mg} / \mathrm{L}$ ) to both ZnO-NPs and zinc ions, while for marine algae, such as Chaetoceros gracilis, Phaeodactylum tricornutum, or Chlorella sp., several orders of higher magnitudes of concentration of $\mathrm{Zn}$ were needed to cause the $50 \%$ inhibition of growth (Franklin et al., 2007; Aruoja et al., 2009; Ji et al., 2011; Peng et al., 2011; Lee and An, 2013). Compared to ZnO-NPs, similar high toxicity of Ag-NPs was found in Pseudokirchneriella subcapitata, with the estimated 96-h EC50 to be 9.9-190 $\mu \mathrm{g} / \mathrm{L}$ (Griffitt et al., 2008; Kennedy et al., 2010). However, higher concentration of Ag-NPs was needed, especially for marine species (up to $1 \mathrm{mg} / \mathrm{L}$ ) to generate a toxic effect (Miao et al., 2009; Oukarroum et al., 2012). Partial contribution of silver ions to Ag-NPs toxicity to Chlamydomonas reinhardtii was found in the inhibition of photosynthesis (Navarro et al., 2008b), whereas the role of silver ion has not been manifested in the other literature reviewed. For $\mathrm{TiO}_{2}-\mathrm{NPs}$, the estimated $72-\mathrm{h} \mathrm{EC50}$ was at the $\mathrm{mg} / \mathrm{L}$ 
Table 3 Toxicity of $\mathrm{ZnO}-\mathrm{NPs}$, Ag-NPs, and $\mathrm{TiO}_{2}-\mathrm{NPs}$ on algae

\begin{tabular}{|c|c|c|c|c|c|c|c|c|}
\hline Algae & $\begin{array}{l}\text { TEM } \\
\text { size } \\
(\mathrm{nm}) \\
\end{array}$ & $\begin{array}{l}\text { Conc. } \\
(\mathrm{mg} / \mathrm{L})\end{array}$ & $\begin{array}{l}\text { Dura- } \\
\text { tion } \\
(\mathrm{h})\end{array}$ & $\begin{array}{l}\text { Nanoparticle } \\
\text { toxicity }\end{array}$ & Ion toxicity & $\begin{array}{l}\text { Bulk material } \\
\text { toxicity }\end{array}$ & $\begin{array}{c}\text { Contribution } \\
\text { of ion to } \\
\text { nanotoxicity }\end{array}$ & Reference \\
\hline \multicolumn{9}{|l|}{ ZnO-NPs: freshwater } \\
\hline \multirow[t]{3}{*}{$\begin{array}{l}\text { Pseudokirchneriella } \\
\quad \text { subcapitata }\end{array}$} & 30 & $\begin{array}{c}0.025- \\
0.600\end{array}$ & 72 & IC50: $49 \mu \mathrm{g} / \mathrm{L}$ & IC50: $69 \mu \mathrm{g} / \mathrm{L}$ & IC50: $63 \mu \mathrm{g} / \mathrm{L}$ & Mainly & $\begin{array}{l}\text { Franklin et al., } \\
\quad 2007\end{array}$ \\
\hline & $50-70$ & $0-0.5$ & 72 & $\begin{array}{c}\text { EC50: } 42 \mu \mathrm{g} / \mathrm{L} ; \\
\text { NOEC }^{*}: 17 \mu \mathrm{g} / \mathrm{L}\end{array}$ & $\begin{array}{l}\text { EC50: } 42 \mu \mathrm{g} / \mathrm{L} \\
\text { NOEC: } 5 \mu \mathrm{g} / \mathrm{L}\end{array}$ & $\begin{array}{l}\text { EC50: } 37 \mu \mathrm{g} / \mathrm{L} ; \\
\text { NOEC: } 20 \mu \mathrm{g} / \mathrm{L}\end{array}$ & Mainly & $\begin{array}{l}\text { Aruoja et al., } \\
\quad 2009\end{array}$ \\
\hline & $<100$ & $0-0.3$ & 72 & $\begin{array}{l}\text { EC50: }<0.05 \mathrm{mg} / \mathrm{L} \\
\text { NOEC: }<0.05 \mathrm{mg} / \mathrm{L}\end{array}$ & & & & $\begin{array}{l}\text { Lee and An, } \\
2013\end{array}$ \\
\hline Chlorella sp. & 20 & $0-1000$ & 144 & $\begin{array}{l}\text { IC50: } 803 \mathrm{mg} / \mathrm{L} \text {; } \\
\text { NOEC: } 5 \mathrm{mg} / \mathrm{L}\end{array}$ & $\begin{array}{l}\text { EC30: } 2 \mathrm{mg} / \mathrm{L} \text {; } \\
\text { NOEC: } 1 \mathrm{mg} / \mathrm{L}\end{array}$ & $\begin{array}{l}\text { IC50: } 803 \mathrm{mg} / \mathrm{L} ; \\
\text { NOEC: } 50 \mathrm{mg} / \mathrm{L}\end{array}$ & Partly & Ji et al., 2011 \\
\hline \multicolumn{9}{|l|}{ ZnO-NPs: marine } \\
\hline \multirow[t]{3}{*}{$\begin{array}{l}\text { Thalassiosia } \\
\text { pseudonana }\end{array}$} & 26.2 & & 96 & IC50: $4.56 \mathrm{mg} / \mathrm{L}$ & IC50: $3.48 \mathrm{mg} / \mathrm{L}$ & IC50: $6.65 \mathrm{mg} / \mathrm{L}$ & Mainly & $\begin{array}{l}\text { Wong et al., } \\
2010\end{array}$ \\
\hline & 20 & & 48 & EC50: $25.5 \mu \mathrm{g} / \mathrm{L}$ & EC50: $76.5 \mu \mathrm{g} / \mathrm{L}$ & & Mainly & $\begin{array}{l}\text { Miao et al. } \\
2010\end{array}$ \\
\hline & $\begin{array}{l}6.3 \\
15.7\end{array}$ & $0-62$ & 72 & IC90: $8 \mathrm{mg} / \mathrm{L}$ & & & Partly & $\begin{array}{l}\text { Peng et al., } \\
2011\end{array}$ \\
\hline $\begin{array}{l}\text { Skeletonema } \\
\text { costatum }\end{array}$ & 26.2 & & 96 & IC50: $1.90 \mathrm{mg} / \mathrm{L}$ & IC50: $1.23 \mathrm{mg} / \mathrm{L}$ & IC50: $2.38 \mathrm{mg} / \mathrm{L}$ & Mainly & $\begin{array}{l}\text { Wong et al., } \\
2010\end{array}$ \\
\hline Chaetoceros gracilis & $\begin{array}{l}6.3 \\
15.7\end{array}$ & $0-62$ & 72 & IC94: $8 \mathrm{mg} / \mathrm{L}$ & & & Partly & $\begin{array}{l}\text { Peng et al., } \\
2011\end{array}$ \\
\hline $\begin{array}{c}\text { Phaeodactylum } \\
\text { tricornutum }\end{array}$ & $\begin{array}{l}6.3 \\
15.7\end{array}$ & $0-62$ & 72 & IC55: $8 \mathrm{mg} / \mathrm{L}$ & & & Partly & $\begin{array}{l}\text { Peng et al., } \\
2011\end{array}$ \\
\hline Dunaliella tertiolecta & $\begin{array}{c}900 \\
(\mathrm{DLS}) \\
\end{array}$ & $0.1-10$ & 96 & $\begin{array}{l}\text { EC50: } 1.94 \mathrm{mg} / \mathrm{L} ; \\
\text { NOEC: } 0.08 \mathrm{mg} / \mathrm{L}\end{array}$ & $\begin{array}{l}\text { EC50: } 0.65 \mathrm{mg} / \mathrm{L} ; \\
\text { NOEC: } 0.01 \mathrm{mg} / \mathrm{L}\end{array}$ & $\begin{array}{l}\text { EC50: } 3.57 \mathrm{mg} / \mathrm{L} ; \\
\text { NOEC: } 0.80 \mathrm{mg} / \mathrm{L}\end{array}$ & Partly & $\begin{array}{l}\text { Manzo et al., } \\
2013 \\
\end{array}$ \\
\hline \multicolumn{9}{|l|}{ Ag-NPs: freshwater } \\
\hline $\begin{array}{l}\text { Chlamydomonas } \\
\text { reinhardtii }\end{array}$ & 25 & & $2-5$ & $\begin{array}{c}\text { 2-h EC50: } \\
112 \mu \mathrm{g} / \mathrm{L}\end{array}$ & $\begin{array}{l}\text { 2-h EC50: } \\
19.6 \mu \mathrm{g} / \mathrm{L}\end{array}$ & & Partly & $\begin{array}{l}\text { Navarro et al., } \\
2008 \mathrm{a}\end{array}$ \\
\hline Chlorella vulgaris & 60 & & 24 & EC33: $1 \mathrm{mg} / \mathrm{L}$ & & & & $\begin{array}{l}\text { Oukarroum et } \\
\text { al., } 2012\end{array}$ \\
\hline \multirow[t]{2}{*}{$\begin{array}{l}\text { Pseudokirchneriella } \\
\quad \text { subcapitata }\end{array}$} & $29-42$ & & 96 & EC50: $9.9 \mu \mathrm{g} / \mathrm{L}$ & & & & $\begin{array}{l}\text { Kennedy et } \\
\text { al., } 2010\end{array}$ \\
\hline & 26.8 & & 96 & IC50: $190 \mu \mathrm{g} / \mathrm{L}$ & & & & $\begin{array}{l}\text { Griffitt et al., } \\
2008\end{array}$ \\
\hline \multicolumn{9}{|l|}{ Ag-NPs: marine } \\
\hline $\begin{array}{c}\text { Thalassiosira } \\
\text { weissflogii }\end{array}$ & $60-70$ & & 48 & $\begin{array}{l}\text { No significant } \\
\text { toxic effects } \\
\text { at } 2.36 \mathrm{mg} / \mathrm{L}\end{array}$ & & & & $\begin{array}{l}\text { Miao et al., } \\
2009\end{array}$ \\
\hline Dunaliella tertiolect & 60 & & 24 & EC44: $1 \mathrm{mg} / \mathrm{L}$ & & & & $\begin{array}{c}\text { Oukarroum et } \\
\text { al., } 2012 \\
\end{array}$ \\
\hline \multicolumn{9}{|l|}{$\mathrm{TiO}_{2}$-NPs: freshwater } \\
\hline \multirow[t]{2}{*}{ Chlorella sp. } & $\begin{array}{c}5-10 \\
\text { Anatase }\end{array}$ & $0-1000$ & 144 & $\begin{array}{l}\text { EC30: } 30 \mathrm{mg} / \mathrm{L} \text {; } \\
\text { IC70.5: } 1000 \mathrm{mg} / \mathrm{L}\end{array}$ & & & & Ji et al., 2011 \\
\hline & $\begin{array}{c}50 \\
\text { Rutile }\end{array}$ & 1000 & 144 & $\begin{array}{l}\text { No significant } \\
\text { toxicity effects at } \\
1000 \mathrm{mg} / \mathrm{L}\end{array}$ & & $\begin{array}{l}\text { No significant } \\
\text { toxicity effects at } \\
1000 \mathrm{mg} / \mathrm{L}\end{array}$ & & Ji et al., 2011 \\
\hline \multirow[t]{5}{*}{$\begin{array}{l}\text { Pseudokirchneriella } \\
\quad \text { subcapitata }\end{array}$} & $25-70$ & $0-100$ & 72 & $\begin{array}{c}\text { EC50: } 58.3 \mathrm{mg} / \mathrm{L} ; \\
\text { NOEC: } 0.984 \mathrm{mg} / \mathrm{L}\end{array}$ & & $\begin{array}{l}\text { EC50: } 35.9 \mathrm{mg} / \mathrm{L} \\
\text { NOEC: } 10.1 \mathrm{mg} / \mathrm{L}\end{array}$ & & $\begin{array}{l}\text { Aruoja et al., } \\
2009\end{array}$ \\
\hline & $<100$ & & 72 & IC25: >100 mg/L & & & & $\begin{array}{l}\text { Blaise et al., } \\
\quad 2008\end{array}$ \\
\hline & $<10$ & $0-250$ & 72 & EC50: $241 \mathrm{mg} / \mathrm{L}$ & & & & $\begin{array}{l}\text { Hartmann et } \\
\text { al., } 2010\end{array}$ \\
\hline & $\begin{array}{c}140 \\
\text { (DLS) }\end{array}$ & $0-100$ & 72 & EC50: $87 \mathrm{mg} / \mathrm{L}$ & & & & $\begin{array}{l}\text { Warheit et al., } \\
2007\end{array}$ \\
\hline & 21 & $0-10$ & 72 & $\begin{array}{l}\text { EC50: } 2.53 \mathrm{mg} / \mathrm{L} ; \\
\text { NOEC: }<0.05 \mathrm{mg} / \mathrm{L}\end{array}$ & & & & $\begin{array}{l}\text { Lee and An, } \\
2013\end{array}$ \\
\hline \multirow[t]{2}{*}{$\begin{array}{l}\text { Chlamydomonas } \\
\text { reinhardtii }\end{array}$} & & $0-100$ & 192 & EC50: $>100 \mathrm{mg} / \mathrm{L}$ & & EC50: $>100 \mathrm{mg} / \mathrm{L}$ & & $\begin{array}{c}\text { Gunawan et } \\
\text { al., } 2013\end{array}$ \\
\hline & 21 & $0-100$ & 120 & IC20:100 mg/L & & & & $\begin{array}{l}\text { Wang et al., } \\
2008\end{array}$ \\
\hline $\begin{array}{r}\text { Desmodesmus } \\
\text { subspicatus }\end{array}$ & 25 & $0-50$ & 72 & EC50:44 mg/L & & & & $\begin{array}{l}\text { Hund-Rinke } \\
\text { and Simon, } \\
2006\end{array}$ \\
\hline \multicolumn{9}{|l|}{$\mathrm{TiO}_{2}$-NPs: marine } \\
\hline $\begin{array}{c}\text { Phaeodactylum } \\
\text { tricornutum }\end{array}$ & $\begin{array}{c}15,25 \\
32\end{array}$ & $0-100$ & 72 & $\begin{array}{c}\text { EC50: } \\
10.9-14.3 \mathrm{mg} / \mathrm{L}\end{array}$ & & EC50: $24-36 \mathrm{mg} / \mathrm{L}$ & & $\begin{array}{l}\text { Clément et al., } \\
2013\end{array}$ \\
\hline
\end{tabular}


levels $(2.53-58.3 \mathrm{mg} / \mathrm{L})$ and in some cases the EC50 was outside of the studied concentration range (e.g., 0-100 mg/L) (Wang et al., 2008; Gunawan et al., 2013). Since the dissolution of $\mathrm{TiO}_{2}$-NPs was less likely to proceed in studied mediums (Schmidt and Vogelsberger, 2006), the contribution of ions to the $\mathrm{TiO}_{2}$-NPs toxicity was negligible. Some studies indicated that the toxicity was more likely due to the generated ROS (Sharma, 2009).

\subsubsection{Zooplankton}

Compared to algae, a relatively narrow range of 48- or 96-h LC50 (50\% lethal concentration) of $\mathrm{ZnO}-\mathrm{NPs}$ was estimated in several zooplanktons (e.g., Tigriopus japonicas, Elasmopus rapax, and Daphnia magna), ranging from 0.85 to $3.2 \mathrm{mg} / \mathrm{L}$ (Table 4). The 48- or 96-h LC50 of zinc ions was slightly lower $(0.76-1.14 \mathrm{mg} / \mathrm{L})$ and the $48-$ or $96-\mathrm{h} \mathrm{LC} 50$ of bulk $\mathrm{ZnO}$ was $0.37-1 \mathrm{mg} / \mathrm{L}$. More than $50 \%$ of the literature reviewed attributed the toxicity of ZnO-NPs to zinc ions, whereas only a few indicated a particle specific toxicity (e.g., differentially gene expression in Daphnia magna) (Poynton et al., 2011). The 48-h LC50 of Ag-NPs Daphnia magna was 0.0018$0.236 \mathrm{mg} / \mathrm{L}$, which was two orders of magnitude lower than that of $\mathrm{ZnO}-\mathrm{NPs}$, and the corresponding 48 -h LC50 for silver ions was $0.8-12.9 \mu \mathrm{g} / \mathrm{L}$. Of all the eight literature reviewed, half of the studies attributed the Ag-NPs toxicity to dissolved silver ions and no mortality was observed even at $500 \mu \mathrm{g} / \mathrm{L}$ Ag-NPs by chelating the dissolved $\mathrm{Ag}^{+}$with cysteine (Zhao and Wang, 2012a). As for $\mathrm{TiO}_{2}$-NPs, a high concentration of $\mathrm{TiO}_{2}-\mathrm{NPs}$ (48-h or 72-h LC50: $>1.3 \mathrm{mg} / \mathrm{L}$ ) was needed to generate $50 \%$ mortality, and in some extreme cases no toxicity effect was observed on the Daphnia magna, even at $20 \mathrm{~g} / \mathrm{L}$ $\mathrm{TiO}_{2}$-NPs (Heinlaan et al., 2008). Additionally, great variations of 48-h LC50 were found between different types of $\mathrm{TiO}_{2}-\mathrm{NPs}$, with the smaller size and anatase type more toxic (48-h LC50: 7.75-35.3 mg/L) (Zhu et al., 2009a; Das et al., 2013; Clément et al., 2013).

\subsubsection{Fish}

Comparatively, fewer acute toxicity studies of these three MNs have been conducted on fish (Table 5, p.586). Toxic effects, such as mortality, retarded hatching, reduced larval body length, and tail malformation, had been observed in zebrafish embryos after exposure to 50 and $100 \mathrm{mg} / \mathrm{L} \mathrm{ZnO-NPs} \mathrm{for}$ $96 \mathrm{~h}$, while zinc ion $(2.152 \mathrm{mg} / \mathrm{L})$ could also cause a retarded hatching as noted in the same study (Zhu et al., 2009b; Bai et al., 2010). The 96-h LC50 of $\mathrm{ZnO}-\mathrm{NPs}$ and bulk $\mathrm{ZnO}$ to larval zebrafish was estimated to be $1.79 \mathrm{mg} / \mathrm{L}$ and $1.55 \mathrm{mg} / \mathrm{L}$, respectively (Ward and Kramer, 2002; Zhu et al., 2008). However, for adult Japanese medaka (Oryzias melastigma), no significant change on superoxide dismutase (SOD) and metallothionein (MT) gene expression was detected after exposure to ZnO-NPs (4 or $40 \mathrm{mg} / \mathrm{L}$ ) for $96 \mathrm{~h}$, or conversely with the zinc ions (Wong et al., 2010). Zinc ions were considered to be partially responsible for the observed $\mathrm{ZnO}-\mathrm{NPs}$ toxicity based on the limited literature reviewed, but more studies are needed to draw a generalized conclusion.

For Ag-NPs, significant accumulation of Ag-NPs in gill and subsequent alteration in gene expression were observed in adult zebrafish after exposure to $50 \mu \mathrm{g} / \mathrm{L} \mathrm{Ag-NPs}$ for $48 \mathrm{~h}$ (Griffitt et al., 2009). The 48-h LC50 of Ag-NPs and silver ions for adult zebrafish were estimated to be 7.07 and $0.022 \mathrm{mg} / \mathrm{L}$, respectively (Griffitt et al., 2008). Minor contribution of silver ions was found in the toxicity study of Ag-NPs $(5-500 \mu \mathrm{g} / \mathrm{L}$ ) to zebrafish embryos (Asharani et al., 2008), but again more studies are needed to draw a generalized conclusion. Size-dependent toxicity was observed for $\mathrm{TiO}_{2}$-NPs to zebrafish embryos, with the 120 -h $\mathrm{LC} 50$ of $\mathrm{TiO}_{2}$-NPs $(5.7$ and $12.4 \mathrm{~nm}$ ) to be 23.4 and $610 \mathrm{mg} / \mathrm{L}$, respectively, but the value was over $1000 \mathrm{mg} / \mathrm{L}$ for $15 \mathrm{~nm}$ sized $\mathrm{TiO}_{2}$-NPs (Kim et al., 2014). Another study showed no impact of $\mathrm{TiO}_{2}$-NPs (size $<20 \mathrm{~nm}$ ) and bulk $\mathrm{TiO}_{2}$ on the hatching of zebrafish embryos, even when the concentration reached as high as $500 \mathrm{mg} / \mathrm{L}$ (Zhu et al., 2008). Similar low toxicity of $\mathrm{TiO}_{2}$-NPs was also observed in Oncorhynchus mykiss, Piaractus mesopotamicus, and Carassius auratus with no or minor impact at an exposure concentration of $100 \mathrm{mg} / \mathrm{L}$ (Warheit et al., 2007; Ates et al., 2013; Clemente et al., 2013). However, direct intraperitoneal injection of $1 \mathrm{ml}$ $(1 \mathrm{mg} / \mathrm{L})$ significantly increased the antioxidant genes (e.g., CAT, GST, and SOD) expression within $6 \mathrm{~h}$ (Varela-Valencia et al., 2014), indicating the low bioavailability of waterborne $\mathrm{TiO}_{2}-\mathrm{NPs}$ as a possible reason for observed low toxicity. 
Table 4 Toxicity of $\mathrm{ZnO}-\mathrm{NPs}$, Ag-NPs, and $\mathrm{TiO}_{2}$-NPs on zooplankton

\begin{tabular}{|c|c|c|c|c|c|c|c|}
\hline Zooplankton & $\begin{array}{l}\text { TEM } \\
\text { size } \\
(\mathrm{nm}) \\
\end{array}$ & $\begin{array}{l}\text { Dura- } \\
\text { tion } \\
(\mathrm{h}) \\
\end{array}$ & $\begin{array}{l}\text { Nanoparticle } \\
\text { toxicity }\end{array}$ & $\begin{array}{l}\text { Ion } \\
\text { toxicity }\end{array}$ & $\begin{array}{c}\text { Bulk } \\
\text { material } \\
\text { toxicity }\end{array}$ & $\begin{array}{l}\text { Contribution } \\
\text { of ion to } \\
\text { nanotoxicity }\end{array}$ & Reference \\
\hline \multicolumn{8}{|l|}{ ZnO-NPs: freshwater } \\
\hline \multirow{7}{*}{$\begin{array}{l}\text { Thamnocephalus } \\
\text { platyurus } \\
\text { Daphnia magna }\end{array}$} & $50-70$ & 24 & $\begin{array}{l}\text { LC50: } 0.18 \mathrm{mg} / \mathrm{L} \\
\text { NOEC: } 0.03 \mathrm{mg} / \mathrm{L}\end{array}$ & & & Mainly & $\begin{array}{l}\text { Heinlaan et al., } \\
\quad 2008\end{array}$ \\
\hline & 30 & $\begin{array}{l}24 \\
48 \\
504\end{array}$ & $\begin{array}{l}\text { 48-h LC 50: } 1.02 \mathrm{mg} / \mathrm{L} ; \\
\text { 24-h EC50: } 1.41 \mathrm{mg} / \mathrm{L} \\
\text { (feeding inhibition); } \\
\text { 21-d EC50: } 0.26 \mathrm{mg} / \mathrm{L} \\
\text { (reproduction) }\end{array}$ & $\begin{array}{l}\text { 48-h LC50: } 0.76 \mathrm{mg} / \mathrm{L} ; \\
\text { 24-h EC50: } 0.8 \mathrm{mg} / \mathrm{L} \\
\text { (feeding inhibition); } \\
\text { 21-d EC50: } \\
0.25-0.4 \mathrm{mg} / \mathrm{L} \\
\text { (reproduction) }\end{array}$ & $\begin{array}{l}\text { 48-h LC50: } 0.89 \mathrm{mg} / \mathrm{L} ; \\
\text { 24-h EC50: } 1.89 \mathrm{mg} / \mathrm{L} \\
\text { (feeding inhibition); } \\
\text { 21-d EC50: } 0.3 \mathrm{mg} / \mathrm{L} \\
\quad \text { (reproduction) }\end{array}$ & Partly & $\begin{array}{l}\text { Lopes et al., } \\
2014\end{array}$ \\
\hline & $80-100$ & $\begin{array}{l}24 \\
48 \\
504\end{array}$ & $\begin{array}{l}\text { 48-h LC50: } 1.10 \mathrm{mg} / \mathrm{L} \text {; } \\
\text { 24-h EC50: } 2.0 \mathrm{mg} / \mathrm{L} \\
\text { (feeding inhibition); } \\
\text { 21-d EC50: } 0.36 \mathrm{mg} / \mathrm{L} \\
\text { (reproduction) }\end{array}$ & & & Mainly & $\begin{array}{l}\text { Lopes et al., } \\
2014\end{array}$ \\
\hline & 27.2 & 24 & $\begin{array}{l}\text { Alteration of gene } \\
\text { expression in cyto- } \\
\text { skeletal transport, } \\
\text { cellular respiration, } \\
\text { and reproduction }\end{array}$ & & & Partly & $\begin{array}{l}\text { Poynton et al., } \\
2011\end{array}$ \\
\hline & $50-70$ & 48 & $\begin{array}{l}\text { LC50: } 3.2 \mathrm{mg} / \mathrm{L} ; \\
\text { NOEC: } 0.5 \mathrm{mg} / \mathrm{L}\end{array}$ & & & Mainly & $\begin{array}{l}\text { Heinlaan et al., } \\
2008\end{array}$ \\
\hline & & 48 & EC50: $1 \mathrm{mg} / \mathrm{L}$ & & $\begin{array}{l}\text { EC10: } 0.60 \mathrm{mg} / \mathrm{L} \\
\text { EC50: } 1 \mathrm{mg} / \mathrm{L}\end{array}$ & & $\begin{array}{l}\text { Wiench et al., } \\
2009\end{array}$ \\
\hline & 20 & 48 & $\begin{array}{l}\text { EC50: } 0.622 \mathrm{mg} / \mathrm{L} \\
\text { LC50: } 1.511 \mathrm{mg} / \mathrm{L}\end{array}$ & & & & Zhu et al., 2009a \\
\hline \multicolumn{8}{|l|}{ ZnO-NPs: marine } \\
\hline Tigriopus japonicus & 26.2 & 96 & LC50: $0.85 \mathrm{mg} / \mathrm{L}$ & LC50: $1.14 \mathrm{mg} / \mathrm{L}$ & LC50: $0.43 \mathrm{mg} / \mathrm{L}$ & Mainly & $\begin{array}{l}\text { Wong et al., } \\
2010\end{array}$ \\
\hline Elasmopus rapax & 26.2 & 96 & LC50: $1.19 \mathrm{mg} / \mathrm{L}$ & LC50: $0.80 \mathrm{mg} / \mathrm{L}$ & LC50: $0.37 \mathrm{mg} / \mathrm{L}$ & Mainly & $\begin{array}{l}\text { Wong et al., } \\
2010\end{array}$ \\
\hline \multicolumn{8}{|l|}{ Ag-NPs: freshwater } \\
\hline Daphnia pulex & 26.7 & 48 & LC50: $40 \mu \mathrm{g} / \mathrm{L}$ & $\mathrm{LC} 50: 8 \mu \mathrm{g} / \mathrm{L}$ & & Partly & $\begin{array}{l}\text { Griffitt et al., } \\
2008\end{array}$ \\
\hline \multirow[t]{7}{*}{ Daphnia magna } & $29-41$ & 48 & LC50: $1.8-97 \mu \mathrm{g} / \mathrm{L}$ & LC50: $0.7 \mu \mathrm{g} / \mathrm{L}$ & & & $\begin{array}{l}\text { Kennedy et al., } \\
2010\end{array}$ \\
\hline & $5-25$ & 48 & LC50: $2-4 \mu \mathrm{g} / \mathrm{L}$ & LC50: $2.3 \mu \mathrm{g} / \mathrm{L}$ & & Mainly & $\begin{array}{l}\text { Asghari et al., } \\
2012\end{array}$ \\
\hline & 20 & $\begin{array}{l}48 \\
504\end{array}$ & $\begin{array}{l}\text { No mortality at } 500 \mu \mathrm{g} / \mathrm{L} \\
\mathrm{Ag}-\mathrm{NPs} \text { after } \mathrm{Ag}^{+} \\
\text {was complexed by } \\
\text { cysteine }(48 \mathrm{~h})\end{array}$ & $\begin{array}{c}\text { 48-h LC50: } 2.51 \mu \mathrm{g} / \mathrm{L} \\
\text { 21-d LC50: } 1.6 \mu \mathrm{g} / \mathrm{L}\end{array}$ & & Mainly & $\begin{array}{l}\text { Zhao and Wang, } \\
2011\end{array}$ \\
\hline & $10-100$ & 48 & $\begin{array}{c}\text { LC50: } \\
\text { Ag-NPs-L: } 28.7 \mu \mathrm{g} / \mathrm{L} ; \\
\text { Ag-NPs-P: } 2.0 \mu \mathrm{g} / \mathrm{L} ; \\
\text { Ag-NPs-S }: 1.1 \mu \mathrm{g} / \mathrm{L}\end{array}$ & LC50: $0.88 \mu \mathrm{g} / \mathrm{L}$ & & Mainly & $\begin{array}{l}\text { Zhao and Wang, } \\
\text { 2012a }\end{array}$ \\
\hline & 12.5 & 48 & LC50: $40.2-65.7 \mu \mathrm{g} / \mathrm{L}$ & LC50: $2.2-12.9 \mu \mathrm{g} / \mathrm{L}$ & & & $\begin{array}{l}\text { Blinova et al., } \\
2013\end{array}$ \\
\hline & 8.4 & 48 & LC50: $54-236.3 \mu \mathrm{g} / \mathrm{L}$ & & & & $\begin{array}{l}\text { Blinova et al., } \\
2013\end{array}$ \\
\hline & $1-10$ & 48 & LC50: $2.75 \mu \mathrm{g} / \mathrm{L}$ & & & & Das et al., 2013 \\
\hline \multicolumn{8}{|l|}{$\mathrm{TiO}_{2}$-NPs: freshwater } \\
\hline \multirow[t]{5}{*}{ Daphnia magna } & $1-10$ & 48 & LC50: $7.75 \mathrm{mg} / \mathrm{L}$ & & & & Das et al., 2013 \\
\hline & $25-70$ & $\begin{array}{l}48 \\
48 \\
504\end{array}$ & $\begin{array}{c}\text { LC50: } \\
\text { 20000 mg/L } \\
\text { 48-h EC50: >100 mg/L; } \\
\text { 21-d NOEC: } 3 \mathrm{mg} / \mathrm{L} ; \\
\text { 21-d EC50: } 26.6 \mathrm{mg} / \mathrm{L}\end{array}$ & & & & $\begin{array}{l}\text { Heinlaan et al., } \\
2008 \\
\text { Wiench et al., } \\
2009\end{array}$ \\
\hline & $<20$ & 48 & $\begin{array}{l}\text { EC50: } 35.3 \mathrm{mg} / \mathrm{L} ; \\
\text { LC50: } 143.387 \mathrm{mg} / \mathrm{L}\end{array}$ & & & & Zhu et al., 2009a \\
\hline & $\begin{array}{c}140 \\
\text { (DLS) }\end{array}$ & 48 & EC50: $>100 \mathrm{mg} / \mathrm{L}$ & & & & $\begin{array}{l}\text { Warheit et al., } \\
2007\end{array}$ \\
\hline & $\begin{array}{c}15,32 \\
25\end{array}$ & 72 & EC50: $1.30-3.44 \mathrm{mg} / \mathrm{L}$ & & EC50: $94.71-250 \mathrm{mg} / \mathrm{L}$ & & $\begin{array}{l}\text { Clément et al., } \\
2013\end{array}$ \\
\hline $\begin{array}{l}\text { Thamnocephalus } \\
\text { platyurus }\end{array}$ & $25-70$ & 24 & $\begin{array}{l}\mathrm{LC} 50:>20 \mathrm{~g} / \mathrm{L} \\
\text { NOEC: }>20 \mathrm{~g} / \mathrm{L}\end{array}$ & & & & $\begin{array}{l}\text { Heinlaan et al., } \\
\quad 2008\end{array}$ \\
\hline $\begin{array}{c}\text { Brachionus } \\
\text { plicatilis }\end{array}$ & $\begin{array}{c}15,32 \\
25\end{array}$ & 48 & $\begin{array}{c}\text { EC50: } \\
5.37-267.3 \mathrm{mg} / \mathrm{L}\end{array}$ & & EC50: $5.37-107 \mathrm{mg} / \mathrm{L}$ & & $\begin{array}{l}\text { Clément et al., } \\
2013\end{array}$ \\
\hline
\end{tabular}

${ }^{*} \mathrm{~L}, \mathrm{P}$, and $\mathrm{S}$ represent lactate, polyvinylpyrrolidone, and sodium dodecylbenzene sulfonate, respectively 
Table 5 Toxicity of $\mathrm{ZnO}-\mathrm{NPs}$, Ag-NPs, and $\mathrm{TiO}_{2}-\mathrm{NPs}$ on freshwater fish

\begin{tabular}{|c|c|c|c|c|c|c|c|}
\hline Fish & $\begin{array}{l}\text { TEM } \\
\text { size } \\
(\mathrm{nm})\end{array}$ & $\begin{array}{l}\text { Duration } \\
\text { (h) }\end{array}$ & $\begin{array}{l}\text { Nanoparticle } \\
\text { toxicity }\end{array}$ & Ion toxicity & $\begin{array}{l}\text { Bulk material } \\
\text { toxicity }\end{array}$ & $\begin{array}{l}\text { Contribution } \\
\text { of ion to } \\
\text { nanotoxicity }\end{array}$ & Reference \\
\hline \multicolumn{8}{|l|}{ ZnO-NPs } \\
\hline $\begin{array}{l}\text { Oryzias } \\
\quad \text { melastigma }\end{array}$ & 26.2 & 96 & $\begin{array}{l}\text { No significant change } \\
\text { on SOD and MT RNA } \\
\text { expression }\end{array}$ & & $\begin{array}{c}\text { Significant } \\
\text { up-regulation of } \\
\text { SOD and MT RNA } \\
\text { expression }\end{array}$ & Mainly & $\begin{array}{l}\text { Wong et al., } \\
2010\end{array}$ \\
\hline $\begin{array}{r}\text { Danio rerio } \\
\text { (embryo) }\end{array}$ & 30 & 96 & $\begin{array}{l}\text { Mortality of embryos: } \\
50 \text { and } 100 \mathrm{mg} / \mathrm{L} \text {; } \\
\text { Retarded hatching: } \\
\quad 1-25 \mathrm{mg} / \mathrm{L} \text {; } \\
\text { Reduced larval growth } \\
\text { and tail malformation: } \\
\quad 10-100 \mathrm{mg} / \mathrm{L}\end{array}$ & $\begin{array}{l}\text { Hatching time } \\
\text { increased } \\
\text { significantly } \\
(2.15 \mathrm{mg} / \mathrm{L})\end{array}$ & & Partly & $\begin{array}{l}\text { Bai et al., } \\
2010\end{array}$ \\
\hline \multirow[t]{2}{*}{$\begin{array}{l}\text { Danio rerio } \\
\text { (larvae) }\end{array}$} & 20 & 96 & $\begin{array}{l}\text { 96-h LC50: } 1.79 \mathrm{mg} / \mathrm{L} \\
\text { 84-h EC50: } 2.06 \mathrm{mg} / \mathrm{L} \\
\text { (hatching) }\end{array}$ & & $\begin{array}{l}\text { 96-h LC50: } 1.55 \mathrm{mg} / \mathrm{L} ; \\
\text { 84-h EC50: } 2.06 \mathrm{mg} / \mathrm{L} \\
\text { (hatching) }\end{array}$ & & $\begin{array}{l}\text { Zhu et al., } \\
\quad 2008\end{array}$ \\
\hline & 20 & 96 & $\begin{array}{l}\text { Reduced hatching and } \\
\text { induction of pericardial } \\
\text { edema at } 72 \mathrm{~h}(50 \text { and } \\
100 \mathrm{mg} / \mathrm{L})\end{array}$ & & & Partly & $\begin{array}{l}\text { Zhu et al., } \\
\text { 2009b }\end{array}$ \\
\hline \multicolumn{8}{|l|}{ Ag-NPs } \\
\hline \multirow[t]{2}{*}{ Danio rerio } & 26.6 & 48 & $\begin{array}{l}\text { LC50: } 7.07 \mathrm{mg} / \mathrm{L} \\
\quad \text { (adult); } \\
\text { LC50: } 7.20 \mathrm{mg} / \mathrm{L} \\
\quad \text { (juvenile) }\end{array}$ & $\begin{array}{l}\text { LC50: } 22 \mu \mathrm{g} / \mathrm{L} \\
\quad \text { (adult); } \\
\text { LC50: }>10 \mathrm{mg} / \mathrm{L} \\
\quad \text { (juvenile) }\end{array}$ & & Minor & $\begin{array}{l}\text { Griffitt et al., } \\
\quad 2008\end{array}$ \\
\hline & 26.6 & 48 & $\begin{array}{l}\text { Different gene } \\
\text { expressions }\end{array}$ & & & Partly & $\begin{array}{l}\text { Griffitt et al., } \\
2009\end{array}$ \\
\hline $\begin{array}{r}\text { Danio rerio } \\
\text { (embryo) }\end{array}$ & $5-20$ & 72 & $\begin{array}{l}\text { Abnormal body axes, } \\
\text { twisted notochord, slow } \\
\text { blood flow, pericardial } \\
\text { edema and cardiac ar- } \\
\text { rhythmia }(5-500 \mu \mathrm{g} / \mathrm{L})\end{array}$ & $\begin{array}{c}\text { No significant } \\
\text { defect in } \\
\text { developing } \\
\text { embryos } \\
(0.26-2.14 \mu \mathrm{g} / \mathrm{L})\end{array}$ & & Minor & $\begin{array}{c}\text { Asharani et } \\
\text { al., } 2008\end{array}$ \\
\hline \multicolumn{8}{|l|}{$\mathrm{TiO}_{2}$-NPs } \\
\hline $\begin{array}{r}\text { Danio rerio } \\
\text { (embryo) }\end{array}$ & $\begin{array}{c}<20 \\
5.7 \\
12.4 \\
15.0\end{array}$ & $\begin{array}{r}96 \\
120\end{array}$ & $\begin{array}{c}\text { No impact on hatching } \\
(500 \mathrm{mg} / \mathrm{L}) \\
\text { LC50: } 23.4 \mathrm{mg} / \mathrm{L}(5.7 \mathrm{~nm}) \\
\text { LC50: } 610 \mathrm{mg} / \mathrm{L}(12.4 \mathrm{~nm}) \\
\text { LC50: }>1000 \mathrm{mg} / \mathrm{L}(15 \mathrm{~nm})\end{array}$ & & $\begin{array}{l}\text { No impact on hatching } \\
(500 \mathrm{mg} / \mathrm{L})\end{array}$ & & $\begin{array}{l}\text { Zhu et al., } \\
2008 \\
\text { Kim et al., } \\
2014\end{array}$ \\
\hline Danio rerio & 20.5 & 48 & $\begin{array}{l}\text { Different gene } \\
\text { expressions }\end{array}$ & & & & $\begin{array}{l}\text { Griffitt et al., } \\
2009\end{array}$ \\
\hline $\begin{array}{l}\text { Oncorhynchus } \\
\quad \text { mykiss }\end{array}$ & $\begin{array}{c}140 \\
(\mathrm{DLS})\end{array}$ & 96 & EC50: $>100 \mathrm{mg} / \mathrm{L}$ & & & & $\begin{array}{l}\text { Warheit et al., } \\
2007\end{array}$ \\
\hline $\begin{array}{l}\text { Oreochromis } \\
\quad \text { niloticus }\end{array}$ & $\begin{array}{c}7,14 \\
21\end{array}$ & 24 & $\begin{array}{l}\text { Alteration of CAT, GST, } \\
\text { and SOD gene expression } \\
(1.0 \mathrm{mg} / \mathrm{L})\end{array}$ & & & & $\begin{array}{l}\text { Varela- } \\
\text { Valencia et } \\
\text { al., } 2014\end{array}$ \\
\hline $\begin{array}{r}\text { Carassius } \\
\text { auratus }\end{array}$ & $\begin{array}{c}432 \\
\text { (DLS) }\end{array}$ & 120 & $\begin{array}{l}\text { Inhibition the growth } \\
\text { by } 19.7 \% \text { at } 100 \mathrm{mg} / \mathrm{L}\end{array}$ & & & & $\begin{array}{l}\text { Ates et al., } \\
2013\end{array}$ \\
\hline $\begin{array}{l}\text { Piaractus } \\
\quad \text { mesopotamicus }\end{array}$ & $\begin{array}{l}543.9 \\
(\mathrm{DLS})\end{array}$ & 96 & No mortality at $100 \mathrm{mg} / \mathrm{L}$ & & & & $\begin{array}{c}\text { Clemente et } \\
\text { al., } 2013\end{array}$ \\
\hline
\end{tabular}

CAT: catalase; GST: glutathione S-transferase; DLS hydrodynamic size is used when a TEM size is not available

4.2 Interpreting the toxicity of MNs and ions: importance of kinetic process for algae, daphnia, and fish

To disengage the impact of ions in the MNs toxicity test, several approaches were applied. The most commonly used approach was to measure the dissolution of MNs during toxicity testing and compare those results with the parallel ion toxicity testing (Franklin et al., 2007; Asharani et al., 2008; Griffitt et al., 2008; Zhu et al., 2008; Aruoja et al., 2009; Bai et al., 2010; Wong et al., 2010; Ji et al., 2011; Lopes et al., 2014). Other approaches, such as adding chelates 
(e.g., cysteine) to reduce the ion bioavailability or studying the toxicity of the filtrates, were also adopted (Zhao and Wang, 2012a; 2012b; Li and Wang, 2013). However, all of these approaches considered that the dissolved ions released from the MNs were constant during their exposure, which is often not necessarily the real case. We attempted to integrate the dissolution and uptake kinetics of MNs to define the role of ions during short-term exposure. Due to the lack of kinetic studies of the MNs uptake in algae, it was not possible to establish the integrated model for algae. Remarkably, the well-developed model in Daphnia magna indicated the minor uptake of ions during short-time exposure was mainly because of the high bioavailability of MNs.

Considering the toxicity of $\mathrm{TiO}_{2}$-NPs to Daphnia, although a high bioaccumulation of $\mathrm{TiO}_{2}-\mathrm{NPs}$ can be commonly observed (Hou et al., 2013), their acute toxicity was comparatively low. For MNs (e.g., $\mathrm{ZnO}-\mathrm{NPs}$ and Ag-NPs) with dissolution, although the contribution of dissolved ions to the total accumulated mass was negligible, their toxicity was extraordinary high, especially for silver ions. Therefore, when considering the toxicity of MNs, the dissolution of MNs as well as specific metal toxicity to certain organisms should not be ignored. Additionally, attention should be paid to the environmentally relevant low concentration of MNs exposure, at which the bioavailability may decrease and become even lower than the dissolved ions (Zhao and Wang, 2012b), leading to an elevated accumulation of ions instead of MNs. For fish, the sites of action of these MNs need to be taken into account when considering their toxicity. The gill and digestion tracts are generally considered to be the primary interaction sites (Handy et al., 2008b). Although the gill was generally considered more sensitive than the gut (Wang, 2013), the permeability of gill cells to MNs appeared to be lower than ions, especially to the aggregated MNs (Handy et al., 2008b). The low bioavailability of Ag-NPs to zebrafish may partly explain the relatively low toxicity of Ag-NPs compared to silver ions (Griffitt et al., 2008). However, there is still a great need for a kinetic uptake study of different MNs to different aquatic organisms. Future studies of integrating toxicodynamics with toxicokinetics may better quantify the observed toxicity (Tan and Wang, 2012).

\section{Conclusions}

As a dynamic entity, several kinetic processes (e.g., dissolution, aggregation, stabilization, and sedimentation) were involved in the transformation of $\mathrm{MNs}$ in the aquatic environment. Different uptake kinetics were involved for the uptake of MNs and dissolved ions. Therefore, unlike the traditional metal exposure, a kinetic point of view should be addressed in $\mathrm{MN}$ toxicological studies. Different dissolution rates were observed in $\mathrm{ZnO}-\mathrm{NPs}, \mathrm{Ag}-\mathrm{NPs}$, and $\mathrm{TiO}_{2}-$ NPs, and their solubilities were also variable in different toxicological studies, leading to a variable and increasing waterborne ion concentration during exposure. On the other hand, varied bioavailability of these MNs and corresponding ions were also found in different aquatic organisms (e.g., algae, zooplankton, and fish). Specifically, the MNs appeared to be more bioavailable to daphnids, rendering a minor contribution of ions during short-term exposure. In addition, partial toxicity of ZnO-NPs and Ag-NPs was attributed to the dissolved ions, while the toxicity of $\mathrm{TiO}_{2}-\mathrm{NPs}$ was mainly due to the generated ROS. Overall, this review emphasizes the importance of integrating physicochemical kinetics and uptake kinetics in evaluating the bioavailability and toxicity of both MNs and dissolved ions. Despite the need for more uptake kinetic studies, the overall understanding of the physiochemical kinetics of MNs (e.g., aggregation, sedimentation, and dissolution) in aquatic environment is also needed to have a systematic evaluation of the bioavailability of MNs to aquatic organisms. In future toxicological studies, more chronic exposures at the environmentally relevant low concentrations are desirable. Transformation of MNs within biological tissues should also be investigated to better understand their toxic mechanisms.

\section{References}

Alsop, D.H., Wood, C.M., 1999. Influence of waterborne cations on zinc uptake and toxicity in rainbow trout, Oncorhynchus mykiss. Canadian Journal of Fisheries and Aquatic Sciences, 56(11):2112-2119. [doi:10.1139/ f99-156]

Aruoja, V., Dubourguier, H.C., Kasemets, K., et al., 2009. Toxicity of nanoparticles of $\mathrm{CuO}, \mathrm{ZnO}$ and $\mathrm{TiO}_{2}$ to microalgae Pseudokirchneriella subcapitata. Science of Total Environment, 407(4):1461-1468. [doi:10.1016/j. scitotenv.2008.10.053]

Asghari, S., Johari, S., Lee, J., et al., 2012. Toxicity of various silver nanoparticles compared to silver ions in Daphnia magna. Journal of Nanobiotechnology, 10(1):14. 
[doi:10.1186/1477-3155-10-14]

Asharani, P.V., Wu, Y.L., Gong, Z.Y., et al., 2008. Toxicity of silver nanoparticles in zebrafish models. Nanotechnology, 19(25):255102. [doi:10.1088/0957-4484/19/25/255102]

Ates, M., Demir, V., Adiguzel, R., et al., 2013. Bioaccumulation, subacute toxicity, and tissue distribution of engineered titanium dioxide nanoparticles in goldfish (Carassius auratus). Journal of Nano-materials, 2013: 460518. [doi:10.1155/2013/460518]

Auffan, M., Bottero, J.Y., Chaneac, C., et al., 2010. Inorganic manufactured nanoparticles: how their physicochemical properties influence their biological effects in aqueous environments. Nanomedicine, 5(6):999-1007. [doi:10. 2217/nnm.10.61]

Bai, W., Zhang, Z., Tian, W., et al., 2010. Toxicity of zinc oxide nanoparticles to zebrafish embryo: a physicochemical study of toxicity mechanism. Journal of Nanoparticle Research, 12(5):1645-1654. [doi:10.1007/ s11051-009-9740-9]

Barron, M.G., Albeke, S., 2000. Calcium control of zinc uptake in rainbow trout. Aquatic Toxicology, 50(3):257-264. [doi:10.1016/S0166-445X(99)00099-5]

Baun, A., Hartmann, N.B., Grieger, K., et al., 2008. Ecotoxicity of engineered nanoparticles to aquatic invertebrates: a brief review and recommendations for future toxicity testing. Ecotoxicology, 17(5):387-395. [doi:10.1007/s10646-008-0208-y]

Bian, S.W., Mudunkotuwa, I.A., Rupasinghe, T., et al., 2011. Aggregation and dissolution of $4 \mathrm{~nm} \mathrm{ZnO}$ nanoparticles in aqueous environments: influence of $\mathrm{pH}$, ionic strength, size, and adsorption of humic acid. Langmuir, 27(10): 6059-6068. [doi:10.1021/la200570n]

Blaise, C., Gagné, F., Férard, J.F., et al., 2008. Ecotoxicity of selected nano-materials to aquatic organisms. Environmental Toxicology, 23(5):591-598. [doi:10.1002/tox. 20402]

Blinova, I., Niskanen, J., Kajankari, P., et al., 2013. Toxicity of two types of silver nanoparticles to aquatic crustaceans Daphnia magna and Thamnocephalus platyurus. Environmental Science and Pollution Research, 20(5): 3456-3463. [doi:10.1007/s11356-012-1290-5]

Brantley, S.L., 2008. Kinetics of mineral dissolution. Brantley, S.L., Kubicki, J.D., White, A.F. (Eds.), Kinetics of Water-Rock Interaction. Springer, New York, p.151-210.

Bury, R.N., Galvez, F., Wood, M.C., 1999. Effects of chloride, calcium, and dissolved organic carbon on silver toxicity: comparison between rainbow tout and fathead minnows. Environmental Toxicology and Chemistry, 18(1):56-62. [doi:10.1002/etc.5620180108]

Cho, E.C., Xie, J., Wurm, P.A., et al., 2009. Understanding the role of surface charges in cellular adsorption versus internalization by selectively removing gold nanoparticles on the cell surface with a I2/KI etchant. Nano Letters, 9(3):1080-1084. [doi:10.1021/n1803487r]

Clément, L., Hurel, C., Marmier, N., 2013. Toxicity of $\mathrm{TiO}_{2}$ nanoparticles to cladocerans, algae, rotifers and plantseffects of size and crystalline structure. Chemosphere, 90(3):1083-1090. [doi:10.1016/j.chemosphere.2012.09. $013]$

Clemente, Z., Castro, V.L., Feitosa, L.O., et al., 2013. Fish exposure to nano- $\mathrm{TiO}_{2}$ under different experimental conditions: Methodological aspects for nanoecotoxicology investigations. Science of Total Environment, 463-464:647-656. [doi:10.1016/j.scitotenv. 2013.06.022]

Clift, M.J.D., Rothen-Rutishauser, B., Brown, D.M., et al., 2008. The impact of different nanoparticle surface chemistry and size on uptake and toxicity in a murine macrophage cell line. Toxicology and Applied Pharmacology, 232(3):418-427. [doi:10.1016/j.taap.2008.06. 009]

Conner, S.D., Schmid, S.L., 2003. Regulated portals of entry into the cell. Nature, 422(6927):37-44. [doi:10.1038/ nature 01451]

Das, P., Xenopoulos, M., Metcalfe, C., 2013. Toxicity of silver and titanium dioxide nanoparticle suspensions to the aquatic invertebrate, Daphnia magna. Bulletin of Environmental Contamination and Toxicology, 91(1): 76-82. [doi:10.1007/s00128-013-1015-6]

David, C.A., Galceran, J., Rey-Castro, C., et al., 2012. Dissolution kinetics and solubility of $\mathrm{ZnO}$ nanoparticles followed by AGNES. The Journal of Physical Chemistry $C$, 116(21):11758-11767. [doi:10.1021/jp301671b]

Delay, M., Dolt, T., Woellhaf, A., et al., 2011. Interactions and stability of silver nanoparticles in the aqueous phase: influence of natural organic matter (NOM) and ionic strength. Journal of Chromatography A, 1218(27): 4206-4212. [doi:10.1016/j.chroma.2011.02.074]

Dokoumetzidis, A., Macheras, P., 2006. A century of dissolution research: from Noyes and Whitney to the biopharmaceutics classification system. International Journal of Pharmaceutics, 321(1-2):1-11. [doi:10.1016/j. ijpharm.2006.07.011]

Fabrega, J., Luoma, S.N., Tyler, C.R., et al., 2011. Silver nanoparticles: behaviour and effects in the aquatic environment. Environment International, 37(2):517-531. [doi:10.1016/j.envint.2010.10.012]

Farré, M., Gajda-Schrantz, K., Kantiani, L., et al., 2009. Ecotoxicity and analysis of nanomaterials in the aquatic environment. Analytical and Bioanalytical Chemistry, 393(1):81-95. [doi:10.1007/s00216-008-2458-1]

Franklin, N.M., Rogers, N.J., Apte, S.C., et al., 2007. Comparative toxicity of nanoparticulate $\mathrm{ZnO}$, bulk $\mathrm{ZnO}$, and $\mathrm{ZnCl}_{2}$ to a freshwater microalga (Pseudokirchneriella subcapitata): the importance of particle solubility. Environmental Science \& Technology, 41(24):8484-8490. [doi:10.1021/es071445r]

Garnham, G., Codd, G., Gadd, G., 1992. Kinetics of uptake and intracellular location of cobalt, manganese and zinc in the estuarine green alga Chlorella salina. Applied Microbiology and Biotechnology, 37(2):270-276. [doi:10.1007/ BF00178183]

Griffitt, R.J., Luo, J., Gao, J., et al., 2008. Effects of particle composition and species on toxicity of metallic nanomaterials in aquatic organisms. Environmental Toxicology and Chemistry, 27(9):1972-1978. [doi:10.1897/08-002.1]

Griffitt, R.J., Hyndman, K., Denslow, N.D., et al., 2009. Comparison of molecular and histological changes in zebrafish gills exposed to metallic nanoparticles. Toxicological Sciences, 107(2):404-415. [doi:10.1093/ toxsci/kfn256] 
Gunawan, C., Sirimanoonphan, A., Teoh, W.Y., et al., 2013. Submicron and nano formulations of titanium dioxide and zinc oxide stimulate unique cellular toxicological responses in the green microalga Chlamydomonas reinhardtii. Journal of Hazardous Materials, 260:984992. [doi:10.1016/j.jhazmat.2013.06.067]

Han, J., Qiu, W., Gao, W., 2010. Potential dissolution and photo-dissolution of $\mathrm{ZnO}$ thin films. Journal of Hazardous Materials, 178(1-3):115-122. [doi:10.1016/j. jhazmat.2010.01.050]

Handy, R.D., Eddy, F.B., 2004. Transport of solutes across biological membranes in eukaryotes: an environmental perspective. van Leeuwen, H.P., Köster, W. (Eds), Physicochemical Kinetics and Transport at Biointerfaces. John Wiley \& Sons, Ltd., USA, p.337-356.

Handy, R.D., Kammer, F., Lead, J., et al., 2008a. The ecotoxicology and chemistry of manufactured nanoparticles. Ecotoxicology, 17(4):287-314. [doi:10.1007/s10646008-0199-8]

Handy, R.D., Henry, T., Scown, T., et al., 2008b. Manufactured nanoparticles: their uptake and effects on fish-a mechanistic analysis. Ecotoxicology, 17(5):396-409. [doi:10. 1007/s10646-008-0205-1]

Hartmann, N.B., von der Kammer, F., Hofmann, T., et al., 2010 Algal testing of titanium dioxide nanoparticles - testing considerations, inhibitory effects and modification of cadmium bioavailability. Toxicology, 269(2-3):190-197. [doi:10.1016/j.tox.2009.08.008]

He, C., Hu, Y., Yin, L., et al., 2010. Effects of particle size and surface charge on cellular uptake and biodistribution of polymeric nanoparticles. Biomaterials, 31(13):36573666. [doi:10.1016/j.biomaterials.2010.01.065]

Heinlaan, M., Ivask, A., Blinova, I., et al., 2008. Toxicity of nanosized and bulk $\mathrm{ZnO}, \mathrm{CuO}$ and $\mathrm{TiO}_{2}$ to bacteria Vibrio fischeri and crustaceans Daphnia magna and Thamnocephalus platyurus. Chemosphere, 71(7):1308-1316. [doi:10.1016/j.chemosphere.2007.11.047]

Heng, D., Cutler, D., Chan, H.K., et al., 2008. What is a suitable dissolution method for drug nanoparticles? Pharmaceutical Research, 25(7):1696-1701. [doi:10. 1007/s11095-008-9560-0]

Hirota, K., Terada, H., 2012. Endocytosis of particle formulations by macrophages and its application to clinical treatment. Brian, C. (Ed.), Molecular Regulation of Endocytosis. InTech, Rijeka, Croatia, p.413-428.

Hofmeister, H., Thiel, S., Dubiel, M., et al., 1997. Synthesis of nanosized silver particles in ion-exchanged glass by electron beam irradiation. Applied Physics Letters, 70(13):1694-1696. [doi:10.1063/1.118672]

Hou, W.C., Westerhoff, P., Posner, J.D., 2013. Biological accumulation of engineered nanomaterials: a review of current knowledge. Environmental Science: Processes \& Impacts, 15:103-122. [doi:10.1039/C2EM30686G]

Hund-Rinke, K., Simon, M., 2006. Ecotoxic effect of photocatalytic active nanoparticles $\left(\mathrm{TiO}_{2}\right)$ on algae and daphnids. Environmental Science and Pollution Research, 13(4):225-232. [doi:10.1065/espr2006.06.311]

Hunter, R.J., 2001. Foundations of Colloid Science, 2nd Edition. Oxford University Press, Oxford, p.45-80.

Ji, J., Long, Z., Lin, D., 2011. Toxicity of oxide nanoparticles to the green algae Chlorella sp. Chemical Engineering Journal, 170(2-3):525-530. [doi:10.1016/j.cej.2010.11. 026]

Kennedy, A.J., Hull, M.S., Bednar, A.J., et al., 2010. Fractionating nanosilver: importance for determining toxicity to aquatic test organisms. Environmental Science \& Technology, 44(24):9571-9577. [doi:10.1021/es1025 382]

Kettler, K., Veltman, K., van de Meent, D., et al., 2014. Cellular uptake of nanoparticles as determined by particle properties, experimental conditions, and cell type. Environmental Toxicology and Chemistry, 33(3):481-492. [doi:10.1002/etc.2470]

Kim, M.S., Louis, K.M., Pedersen, J.A., et al., 2014. Using citrate-functionalized $\mathrm{TiO}_{2}$ nanoparticles to study the effect of particle size on zebrafish embryo toxicity. The Analyst, 139(5):964-972. [doi:10.1039/c3an01966g]

Kittler, S., Greulich, C., Diendorf, J., et al., 2010. Toxicity of silver nanoparticles increases during storage because of slow dissolution under release of silver ions. Chemistry of Materials, 22(16):4548-4554. [doi:10.1021/cm100023p]

Klaine, S.J., Alvarez, P.J.J., Batley, G.E., et al., 2008. Nanomaterials in the environment: behavior, fate, bioavailability, and effects. Environmental Toxicology and Chemistry, 27(9):1825-1851. [doi:10.1897/08-090.1]

Knauss, K.G., Dibley, M.J., Bourcier, W.L., et al., 2001. Ti(IV) hydrolysis constants derived from rutile solubility measurements made from 100 to $300{ }^{\circ} \mathrm{C}$. Applied Geochemistry, 16(9-10):1115-1128. [doi:10.1016/S08832927(00)00081-0]

Laban, G., Nies, L., Turco, R., et al., 2010. The effects of silver nanoparticles on fathead minnow (Pimephales promelas) embryos. Ecotoxicology, 19(1):185-195. [doi:10.1007/ s10646-009-0404-4]

Lam, K.S., Wang, W.X., 2006. Accumulation and elimination of aqueous and dietary silver in Daphnia magna. Chemosphere, 64(1):26-35. [doi:10.1016/j.chemosphere. 2005.12.023]

Lee, D.Y., Fortin, C., Campbell, P.G.C., 2004. Influence of chloride on silver uptake by two green algae, Pseudokirchneriella subcapitata and Chlorella pyrenoidosa. Environmental Toxicology and Chemistry, 23(4):10121018. [doi:10.1897/03-145]

Lee, W.M., An, Y.J., 2013. Effects of zinc oxide and titanium dioxide nanoparticles on green algae under visible, UVA, and UVB irradiations: no evidence of enhanced algal toxicity under UV pre-irradiation. Chemosphere, 91(4): 536-544. [doi:10.1016/j.chemosphere.2012.12.033]

Li, W.M., Wang, W.X., 2013. Distinct biokinetic behavior of $\mathrm{ZnO}$ nanoparticles in Daphnia magna quantified by synthesizing ${ }^{65} \mathrm{Zn}$ tracer. Water Research, 47(2):895-902. [doi:10.1016/j.watres.2012.11.018]

Li, X., Lenhart, J.J., Walker, H.W., 2012. Aggregation kinetics and dissolution of coated silver nanoparticles. Langmuir, 28(2):1095-1104. [doi:10.1021/la202328n]

Liu, J., Hurt, R.H., 2010. Ion release kinetics and particle persistence in aqueous nano-silver colloids. Environmental Science \& Technology, 44(6):2169-2175. [doi:10. 1021/es9035557]

Lopes, S., Ribeiro, F., Wojnarowicz, J., et al., 2014. Zinc oxide 
nanoparticles toxicity to Daphnia magna: size-dependent effects and dissolution. Environmental Toxicology and Chemistry, 33(1):190-198. [doi:10.1002/etc.2413]

Lu, F., Wu, S.H., Hung, Y., et al., 2009. Size effect on cell uptake in well-suspended, uniform mesoporous silica nanoparticles. Small, 5(12):1408-1413. [doi:10.1002/smll. 200900005]

Lubick, N., 2008. Nanosilver toxicity: ions, nanoparticles or both? Environmental Science \& Technology, 42(23): 8617-8617. [doi:10.1021/es8026314]

Ma, H., Williams, P.L., Diamond, S.A., 2013. Ecotoxicity of manufactured $\mathrm{ZnO}$ nanoparticles-a review. Environmental Pollution, 172:76-85. [doi:10.1016/j.envpol.2012. 08.011]

Ma, R., Levard, C., Marinakos, S.M., et al., 2012. Sizecontrolled dissolution of organic-coated silver nanoparticles. Environmental Science \& Technology, 46(2):752759. [doi:10.1021/es201686j]

MacInnis, I.N., Brantley, S.L., 1992. The role of dislocations and surface morphology in calcite dissolution. Geochimica et Cosmochimica Acta, 56(3):1113-1126. [doi:10. 1016/0016-7037(92)90049-O]

Manzo, S., Miglietta, M.L., Rametta, G., et al., 2013. Toxic effects of $\mathrm{ZnO}$ nanoparticles towards marine algae Dunaliella tertiolecta. Science of The Total Environment, 445-446:371-376. [doi:10.1016/j.scitotenv.2012.12.051]

Marambio-Jones, C., Hoek, E.V., 2010. A review of the antibacterial effects of silver nanomaterials and potential implications for human health and the environment. Journal of Nanoparticle Research, 12(5):1531-1551. [doi:10.1007/s11051-010-9900-y]

Matranga, V., Corsi, I., 2012. Toxic effects of engineered nanoparticles in the marine environment: model organisms and molecular approaches. Marine Environmental Research, 76:32-40. [doi:10.1016/j.marenvres.2012.01. 006]

Miao, A.J., Wang, W.X., 2004. Relationships between cellspecific growth rate and uptake rate of cadmium and zinc by a coastal diatom. Marine Ecology Progress Series, 275:103-113. [doi:10.3354/meps275103]

Miao, A.J., Schwehr, K.A., Xu, C., et al., 2009. The algal toxicity of silver engineered nanoparticles and detoxification by exopolymeric substances. Environmental Pollution, 157(11):3034-3041. [doi:10.1016/j.envpol. 2009.05.047]

Miao, A.J., Zhang, X.Y., Luo, Z., et al., 2010. Zinc oxide-engineered nanoparticles: dissolution and toxicity to marine phytoplankton. Environmental Toxicology and Chemistry, 29(12):2814-2822. [doi:10.1002/etc.340]

Mihranyan, A., Strømme, M., 2007. Solubility of fractal nanoparticles. Surface Science, 601(2):315-319. [doi:10. 1016/j.susc.2006.09.037]

Misra, S.K., Dybowska, A., Berhanu, D., et al., 2012. The complexity of nanoparticle dissolution and its importance in nanotoxicological studies. Science of The Total Environment, 438:225-232. [doi:10.1016/j.scitotenv.2012. 08.066]

Mudunkotuwa, I.A., Rupasinghe, T., Wu, C.M., et al., 2012. Dissolution of $\mathrm{ZnO}$ nanoparticles at circumneutral $\mathrm{pH}$ : a study of size effects in the presence and absence of citric acid. Langmuir, 28(1):396-403. [doi:10.1021/la203542x]

Navarro, E., Baun, A., Behra, R., et al., 2008a. Environmental behavior and ecotoxicity of engineered nanoparticles to algae, plants, and fungi. Ecotoxicology, 17(5):372-386. [doi:10.1007/s10646-008-0214-0]

Navarro, E., Piccapietra, F., Wagner, B., et al., 2008b. Toxicity of silver nanoparticles to Chlamydomonas reinhardtii. Environmental Science \& Technology, 42(23):8959-8964. [doi:10.1021/es801785m]

Oukarroum, A., Bras, S., Perreault, F., et al., 2012. Inhibitory effects of silver nanoparticles in two green algae, Chlorella vulgaris and Dunaliella tertiolecta. Ecotoxicology and Environmental Safety, 78:80-85. [doi:10. 1016/j.ecoenv.2011.11.012]

Ovečka, M., Lang, I., Baluška, F., et al., 2005. Endocytosis and vesicle trafficking during tip growth of root hairs. Protoplasma, 226(1-2):39-54. [doi:10.1007/s00709-0050103-9]

Pan, Z., Tao, J., Zhu, Y., et al., 2010. Spontaneous growth of $\mathrm{ZnCO}_{3}$ nanowires on $\mathrm{ZnO}$ nanostructures in normal ambient environment: unstable $\mathrm{ZnO}$ nanostructures. Chemistry of Materials, 22(1):149-154. [doi:10.1021/ $\mathrm{cm} 902734 \mathrm{e}]$

Peng, X., Palma, S., Fisher, N.S., et al., 2011. Effect of morphology of $\mathrm{ZnO}$ nanostructures on their toxicity to marine algae. Aquatic Toxicology, 102(3-4):186-196. [doi:10.1016/j.aquatox.2011.01.014]

Piccapietra, F., Allué, C.G., Sigg, L., et al., 2012. Intracellular silver accumulation in Chlamydomonas reinhardtii upon exposure to carbonate coated silver nanoparticles and silver nitrate. Environmental Science \& Technology, 46(13): 7390-7397. [doi:10.1021/es300734m]

Piccinno, F., Gottschalk, F., Seeger, S., et al., 2012. Industrial production quantities and uses of ten engineered nanomaterials in Europe and the world. Journal of Nanoparticle Research, 14(9):1-11. [doi:10.1007/s11051012-1109-9]

Podila, R., Brown, J.M., 2013. Toxicity of engineered nanomaterials: a physicochemical perspective. Journal of Biochemical and Molecular Toxicology, 27(1):50-55. [doi:10.1002/jbt.21442]

Poynton, H.C., Lazorchak, J.M., Impellitteri, C.A., et al., 2011. Differential gene expression in Daphnia magna suggests distinct modes of action and bioavailability for $\mathrm{ZnO}$ nanoparticles and $\mathrm{Zn}$ ions. Environmental Science \& Technology, 45(2):762-768. [doi:10.1021/es102501z]

Reed, R.B., Ladner, D.A., Higgins, C.P., et al., 2012. Solubility of nano-zinc oxide in environmentally and biologically important matrices. Environmental Toxicology and Chemistry, 31(1):93-99. [doi:10.1002/etc.708]

Reidy, B., Haase, A., Luch, A., et al., 2013. Mechanisms of silver nanoparticle release, transformation and toxicity: a critical review of current knowledge and recommendations for future studies and applications. Materials, 6(6): 2295-2350. [doi:10.3390/ma6062295]

Rejman, J., Oberle, V., Zuhorn, I.S., et al., 2004. Sizedependent internalization of particles via the pathways of clathrin- and caveolae-mediated endocytosis. Biochemical Journal, 377(1):159-169. [doi:10.1042/BJ20031253] 
Schmidt, J., Vogelsberger, W., 2006. Dissolution kinetics of titanium dioxide nanoparticles: the observation of an unusual kinetic size effect. The Journal of Physical Chemistry B, 110(9):3955-3963. [doi:10.1021/jp0553611]

Scown, T.M., van Aerle, R., Tyler, C.R., 2010. Review: do engineered nanoparticles pose a significant threat to the aquatic environment? Critical Reviews in Toxicology, 40(7):653-670. [doi:10.3109/10408444.2010.494174]

Sharma, V.K., 2009. Aggregation and toxicity of titanium dioxide nanoparticles in aquatic environment-a review. Journal of Environmental Science and Health, Part A, 44(14):1485-1495. [doi:10.1080/10934520903263231]

Shaw, B.J., Handy, R.D., 2011. Physiological effects of nanoparticles on fish: a comparison of nanometals versus metal ions. Environment International, 37(6):1083-1097. [doi:10.1016/j.envint.2011.03.009]

Smith, C.J., Shaw, B.J., Handy, R.D., 2007. Toxicity of single walled carbon nanotubes to rainbow trout, (Oncorhynchus mykiss): respiratory toxicity, organ pathologies, and other physiological effects. Aquatic Toxicology, 82(2): 94-109. [doi:10.1016/j.aquatox.2007.02.003]

Sotiriou, G.A., Meyer, A., Knijnenburg, J.T.N., et al., 2012. Quantifying the origin of released $\mathrm{Ag}^{+}$ions from nanosilver. Langmuir, 28(45):15929-15936. [doi:10. 1021/la303370d]

Tan, Q.G., Wang, W.X., 2008. The influences of ambient and body calcium on cadmium and zinc accumulation in Daphnia magna. Environmental Toxicology and Chemistry, 27(7):1605-1613. [doi:10.1897/07-592.1]

Tan, Q.G., Wang, W.X., 2012. Two-compartment toxicokinetictoxicodynamic model to predict metal toxicity in Daphnia magna. Environmental Science \& Technology, 46(17): 9709-9715. [doi:10.1021/es301987u]

Ting, Y.P., Lawson, F., Prince, I.G., 1989. Uptake of cadmium and zinc by the alga Chlorella vulgaris: Part 1. Individual ion species. Biotechnology and Bioengineering, 34(7): 990-999. [doi:10.1002/bit.260340713]

Tinke, A.P., Vanhoutte, K., de Maesschalck, R., et al., 2005. A new approach in the prediction of the dissolution behavior of suspended particles by means of their particle size distribution. Journal of Pharmaceutical and Biomedical Analysis, 39(5):900-907. [doi:10.1016/j.jpba.2005.05. 014]

Varela-Valencia, R., Gómez-Ortiz, N., Oskam, G., et al., 2014. The effect of titanium dioxide nanoparticles on antioxidant gene expression in tilapia (Oreochromis niloticus). Journal of Nanoparticle Research, 16(4):1-12. [doi:10.1007/s11051-014-2369-3]

Wang, J., Flanagan, D.R., 2002. General solution for diffusion-controlled dissolution of spherical particles. 2. Evaluation of experimental data. Journal of Pharmaceutical Sciences, 91(2):534-542. [doi:10.1002/jps.10039]

Wang, J., Wang, W.X., 2014. Salinity influences on the uptake of silver nanoparticles and silver nitrate by marine medaka (Oryzias melastigma). Environmental Toxicology and Chemistry, 33(3):632-640. [doi:10.1002/etc.2471]

Wang, J., Zhang, X., Chen, Y., et al., 2008. Toxicity assessment of manufactured nanomaterials using the unicellular green alga Chlamydomonas reinhardtii. Chemosphere, 73(7):1121-1128. [doi:10.1016/j.chemosphere.2008.07. 040]
Wang, W.X., 2011. Ecotoxicology and Biogeochemistry of Trace Metals. Science Press, Beijing, China, p.118-119 (in Chinese).

Wang, W.X., 2013. Dietary toxicity of metals in aquatic animals: recent studies and perspectives. Chinese Science Bulletin, 58(2):203-213. [doi:10.1007/s11434-012-54137]

Wang, W.X., Fisher, N., 1997. Modeling metal bioavailability for marine mussels. Ware, G. (Ed.), Reviews of Environmental Contamination and Toxicology. Springer, New York, p.39-65.

Wang, W.X, Fisher, N.S., Luoma, S.N., 1996. Kinetic determinations of trace element bioaccumulation in the mussel, Mytilus edulis. Marine Ecology Progress Series, 140:91-113. [doi:10.3354/meps140091]

Wang, Y., Miao, A.J., Luo, J., et al., 2013. Bioaccumulation of cdte quantum dots in a freshwater alga Ochromonas danica: a kinetics study. Environmental Science \& Technology, 47(18):10601-10610. [doi:10.1021/es4017 188]

Ward, J.E., Kach, D.J., 2009. Marine aggregates facilitate ingestion of nanoparticles by suspension-feeding bivalves. Marine Environmental Research, 68(3):137-142. [doi:10. 1016/j.marenvres.2009.05.002]

Ward, T.J., Kramer, J.R., 2002. Silver speciation during chronic toxicity tests with the mysid, Americamysis bahia. Comparative Biochemistry and Physiology Part C: Toxicology \& Pharmacology, 133(1-2):75-86. [doi:10. 1016/S1532-0456(02)00082-0]

Warheit, D.B., Hoke, R.A., Finlay, C., et al., 2007. Development of a base set of toxicity tests using ultrafine $\mathrm{TiO}_{2}$ particles as a component of nanoparticle risk management. Toxicology Letters, 171(3):99-110. [doi:10. 1016/j.toxlet.2007.04.008]

Webb, N.A., Wood, C.M., 2000. Bioaccumulation and distribution of silver in four marine teleosts and two marine elasmobranchs: influence of exposure duration, concentration, and salinity. Aquatic Toxicology, 49(1-2): 111-129. [doi:10.1016/S0166-445X(99)00063-6]

Wessels, J.G.H., 1993. Wall growth, protein excretion and morphogenesis in fungi. New Phytologist, 123(3):397413. [doi:10.1111/j.1469-8137.1993.tb03751.x]

Wiench, K., Wohlleben, W., Hisgen, V., et al., 2009. Acute and chronic effects of nano- and non-nano-scale $\mathrm{TiO}_{2}$ and $\mathrm{ZnO}$ particles on mobility and reproduction of the freshwater invertebrate Daphnia magna. Chemosphere, 76(10):1356-1365. [doi:10.1016/j.chemosphere.2009.06. 025]

Wong, S.Y., Leung, P.Y., Djurišić, A.B., et al., 2010. Toxicities of nano zinc oxide to five marine organisms: influences of aggregate size and ion solubility. Analytical and Bioanalytical Chemistry, 396(2):609-618. [doi:10.1007/ s00216-009-3249-z]

Wood, C.M., Grosell, M., Hogstrand, C., et al., 2002. Kinetics of radiolabelled silver uptake and depuration in the gills of rainbow trout (Oncorhynchus mykiss) and European eel (Anguilla anguilla): the influence of silver speciation. Aquatic Toxicology, 56(3):197-213. [doi:10.1016/S0166445X(01)00182-5]

Wood, C.M., McDonald, M.D., Walker, P., et al., 2004. Bioavailability of silver and its relationship to ionoregulation 
and silver speciation across a range of salinities in the gulf toadfish (Opsanus beta). Aquatic Toxicology, 70(2):137157. [doi:10.1016/j.aquatox.2004. 08.002]

$\mathrm{Xu}$, Y., Wang, W.X., 2002. Exposure and potential food chain transfer factor of $\mathrm{Cd}, \mathrm{Se}$ and $\mathrm{Zn}$ in marine fish Lutjanus argentimaculatus. Marine Ecology Progress Series, 238: 173-186. [doi:10.3354/meps238173]

Yang, X., Gondikas, A.P., Marinakos, S.M., et al., 2012. Mechanism of silver nanoparticle toxicity is dependent on dissolved silver and surface coating in Caenorhabditis elegans. Environmental Science \& Technology, 46(2): 1119-1127. [doi:10.1021/es202417t]

Zemke-White, W.L., Clements, K.D., Harris, P.J., 2000. Acid lysis of macroalgae by marine herbivorous fishes: effects of acid pH on cell wall porosity. Journal of Experimental Marine Biology and Ecology, 245(1):57-68. [doi:10. 1016/S0022-0981(99)00151-3]

Zhang, L., Wang, W.X., 2007. Waterborne cadmium and zinc uptake in a euryhaline teleost Acanthopagrus schlegeli acclimated to different salinities. Aquatic Toxicology, 84(2):173-181. [doi:10.1016/j.aquatox.2007.03.027]

Zhang, W., Yao, Y., Sullivan, N., et al., 2011. Modeling the primary size effects of citrate-coated silver nanoparticles on their ion release kinetics. Environmental Science \& Technology, 45(10):4422-4428. [doi:10.1021/es104205a]

Zhao, C.M., Wang, W.X., 2010. Biokinetic uptake and efflux of silver nanoparticles in Daphnia magna. Environmental Science \& Technology, 44(19):7699-7704. [doi:10.1021/ es101484s]
Zhao, C.M., Wang, W.X., 2011. Comparison of acute and chronic toxicity of silver nanoparticles and silver nitrate to Daphnia magna. Environmental Toxicology and Chemistry, 30(4):885-892. [doi:10.1002/etc.451]

Zhao, C.M., Wang, W.X., 2012a. Importance of surface coatings and soluble silver in silver nanoparticles toxicity to Daphnia magna. Nanotoxicology, 6(4):361-370. [doi:10.3109/17435390.2011.579632]

Zhao, C.M., Wang, W.X., 2012b. Size-dependent uptake of silver nanoparticles in Daphnia magna. Environmental Science \& Technology, 46(20):11345-11351. [doi:10. 1021/es3014375]

Zhu, X., Zhu, L., Duan, Z., et al., 2008. Comparative toxicity of several metal oxide nanoparticle aqueous suspensions to zebrafish (Danio rerio) early developmental stage. Journal of Environmental Science and Health, Part A, 43(3):278-284. [doi:10.1080/10934520701792779]

Zhu, X., Zhu, L., Chen, Y., et al., 2009a. Acute toxicities of six manufactured nanomaterial suspensions to Daphnia magna. Journal of Nanoparticle Research, 11(1):67-75. [doi:10.1007/s11051-008-9426-8]

Zhu, X., Wang, J., Zhang, X., et al., 2009b. The impact of ZnO nanoparticle aggregates on the embryonic development of zebrafish (Danio rerio). Nanotechnology, 20(19): 195103. [doi:10.1088/0957-4484/20/19/195103]

Zhu, X., Chang, Y., Chen, Y., 2010. Toxicity and bioaccumulation of $\mathrm{TiO}_{2}$ nanoparticle aggregates in Daphnia magna. Chemosphere, 78(3):209-215. [doi:10.1016/j.chemosphere. 2009.11.013]

\section{中文㒘要:}

\section{本文题目: 从金属纳米颗粒的理化性质以及生物吸收动力学角度探究金属纳米颗粒对水生生物的毒性} Significance of physicochemical and uptake kinetics in controlling the toxicity of metallic nanomaterials to aquatic organisms

研究目的: 研究金属纳米颗粒在进入水体后的一系列动力学过程对金属纳米颗粒的生物可利用性和毒性 可能产生的影响。

研究方法: 针对在毒性测试中金属纳米颗粒的解析现象, 选取三种常见的金属纳米颗粒（纳米氧化锌、 纳米银和纳米二氧化钛), 总结了它们在毒性测试中的解析动力学、溶解性以及毒性。同时, 综合水生生物对金属纳米颗粒以及离子的吸收动力学, 利用动态模型进行模拟, 阐述解离的 离子在生物对金属纳米颗粒吸收中的贡献。

重要结论: 在评价金属纳米颗粒和解析离子对水生生物的生物利用度和毒性的测试过程中, 需要综合考 虑金属纳米颗粒的理化性质以及生物吸收动力学过程。

关键词组: 金属纳米颗粒; 解析; 动力学; 水生生物; 毒性 